Article

\title{
Geochemical and Sr-Nd-Pb-Hf Isotopic Characteristics of Muchen Pluton in Southeast China, Constrain the Petrogenesis of Alkaline A-Type Magma
}

\author{
Haiyang Yan ${ }^{1,2,3}$, Fangyue Wang ${ }^{1,2, *}$, Hai-Ou Gu ${ }^{1,2}$, He Sun ${ }^{1,2}$ and Can Ge ${ }^{1,2,3}$ \\ 1 Isotope Laboratory, School of Resources and Environmental Engineering, Hefei University of Technology, \\ Hefei 230009, China; hyyan1223@163.com (H.Y.); haiougu@hfut.edu.cn (H.-O.G.); sunhe@hfut.edu.cn (H.S.); \\ gecan@hfut.edu.cn (C.G.) \\ 2 Ore Deposit and Exploration Center (ODEC), Hefei University of Technology, Hefei 230009, China \\ 3 Laboratory of three-dimensional exploration for Mineral District, Hefei University of Technology, \\ Hefei 230009, China \\ * Correspondence: fywang@hfut.edu.cn
}

Received: 2 December 2019; Accepted: 15 January 2020; Published: 19 January 2020

\begin{abstract}
We present comprehensive petrological, major-trace element, in situ zircon U-Pb dating and $\mathrm{Sr}-\mathrm{Nd}-\mathrm{Pb}$ isotopic data for Muchen granitoid (western Zhejiang Province, Southeast China), to constrain the petrogenesis of alkaline A-type granites and the geodynamic setting of Southeast China in the Early Cretaceous. The Early Cretaceous Muchen quartz monzonite yielded zircon $\mathrm{U}-\mathrm{Pb}$ crystallization ages of $111.3 \pm 0.7 \mathrm{Ma}$ and is metaluminous to weakly peraluminous with $\mathrm{SiO}_{2}$ contents ranging from 59 to $69 \mathrm{wt} . \%$, and can be classified as alkaline A-type granitoid. The quartz monzonites have low $\left({ }^{87} \mathrm{Sr} /{ }^{86} \mathrm{Sr}\right)_{i}$ values $(0.7052$ to 0.7061$)$ and high $\varepsilon_{\mathrm{Nd}}(t)$ values $(-2.6$ to -2.0$)$, similar to nearby coeval mafic rocks that have been proposed to be derived from the enriched lithospheric mantle. The high $\mathrm{Nb} / \mathrm{Ta}$ ratios (16.7 to 30.1 , average 21.8 ) and low $\mathrm{Nb} / \mathrm{U}$ ratios (as low as 3.5) indicate the involvement of slab-derived melt and fluids in this mantle. These geochemical properties of the Muchen quartz monzonites indicated that they might be from a phlogopite-bearing and rutile-rich subduction-modified subcontinental lithospheric mantle, and underwent strong fractional crystallization of olivine + orthopyroxene + plagioclase during magma ascent. The low Mg\# values of these alkaline rocks ( $<30$ mostly) may indicate a low-pressure source in a back-arc setting. The early Cretaceous alkaline granitoids in Southeast China are related to the continental back-arc setting caused by deep angle subduction of the paleo-Pacific plate.
\end{abstract}

Keywords: subducted melts/fluids; alkaline A-type magma; deep angle subduction; high $\mathrm{Nb} / \mathrm{Ta}$; paleo-Pacific plate; SE China

\section{Introduction}

Widespread Mesozoic igneous rocks in Southeast China [1,2], were mainly emplaced in the Jurassic and Cretaceous periods [3,4]. The majority of the Cretaceous igneous rocks are calc-alkaline [5-8], but some Cretaceous A-type granites or alkaline intrusions also occur [2,9-13]. A-type granites or alkaline intrusions generally develop during continental extension in post-orogenic or intraplate settings [14-17], and can be used to investigate lithospheric sources and magma evolution of these rocks, and geodynamic processes. Previous studies have provided petrological, geochemical, and isotopic constraints on the origin and evolution of A-type granites, leading to several models such as a low degree of partial melting of dry granulitic residue depleted by the prior extraction of granitic melt [18,19], partial melting 
of tholeiitic rock derived from underplated mafic magma in the crust [20,21], re-melting metaluminous and peraluminous tonalite or granodiorite [22,23], fractional crystallization from mafic magmas with or without crustal assimilation [24-27], and magma mixing between mantle-derived and crust-derived magma [28-32]. Essentially, these models fall into three categories: crustal source, mantle source, and mixing source between crustal and mantle. However, previous studies show that A-type granites in SE China are generally high-silica $\left(\mathrm{SiO}_{2}>70 \mathrm{wt}\right.$.\%) rocks $[9,13,33-36]$, making it difficult to determine whether mantle materials have been involved in their formation. Therefore, understanding the features of low- $\mathrm{SiO}_{2}$ alkaline rocks can provide important insights into the petrogenesis of the A-type granitoids.

In this paper, we collected 9 samples from Muchen pluton in Zhejiang Province, SE China (GPS: $28^{\circ} 50^{\prime} 22.4^{\prime \prime} \mathrm{N}, 119^{\circ} 09^{\prime} 10.1^{\prime \prime} \mathrm{E}$ ). These samples are alkaline granitoids, with $\mathrm{SiO}_{2} \approx 60-70 \mathrm{wt} . \%$. Previous paper considered that these rocks were derived from a hybrid magma produced by mixing between depleted mantle-derived mafic magmas and felsic magmas generated by partial melting of crustal materials, and were classified into I-type granitoids [30]. Here, we propose a counter-argument that these rocks are not a hybrid origin between the depleted mantle and crustal materials, and not I-type granitoids.

\section{Geological Background and Petrography}

South China, located on the eastern margin of Eurasia, consists of the Yangtze Block and Cathaysia Block. The specific location of South China is the south of the North China Craton, northeast of the Indochina Block, east of the Tibetan Plateau, and west of the Philippine Sea Plate (Figure 1; [37-41]. There is a consensus that the Yangtze Block and Cathaysia Block collided during the Neoproterozoic to form the South China Block. Subsequently, the South China Block began to collide with the Indochina Block and North China Block during the Triassic. Finally, the Yanshanian orogeny events of the South China Block produced widely distributed Mesozoic igneous rocks, including the widespread granitoids province in SE China (Figure 1). Early and Late Yanshanian granitic rocks are mainly distributed in inland and coastal areas of SE China, respectively. Generally, the Cretaceous magmatism along the coastal area was produced under an active continental margin setting that is related to the subduction of the paleo-Pacific plate [42,43].

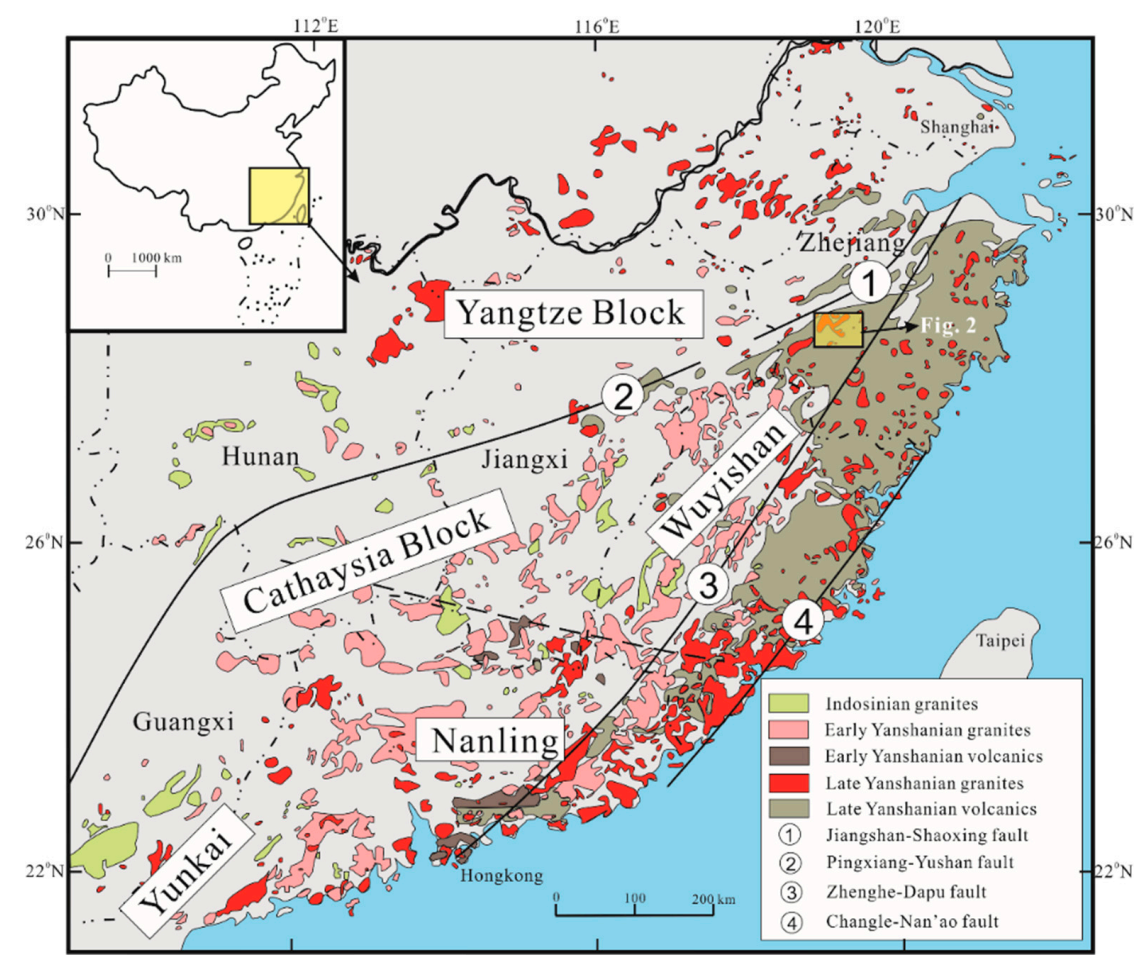

Figure 1. Simplified geological map of South China showing the distribution of Mesozoic granitoid and volcanic rocks (modified after Liu et al. [30]). 
Muchen pluton is located in Longyou County, Zhejiang Province, Southeast China (Figures 1 and 2). The north of this pluton is hosted in the Proterozoic metamorphic and igneous rocks and the south is the Late Jurassic igneous and sedimentary rocks. The area stretches over $\sim 60 \mathrm{~km}^{2}$ along NE to NNE trending. Moreover, small elliptical plutons of granite or granodiorite crop out near the Muchen pluton (Figure 2).

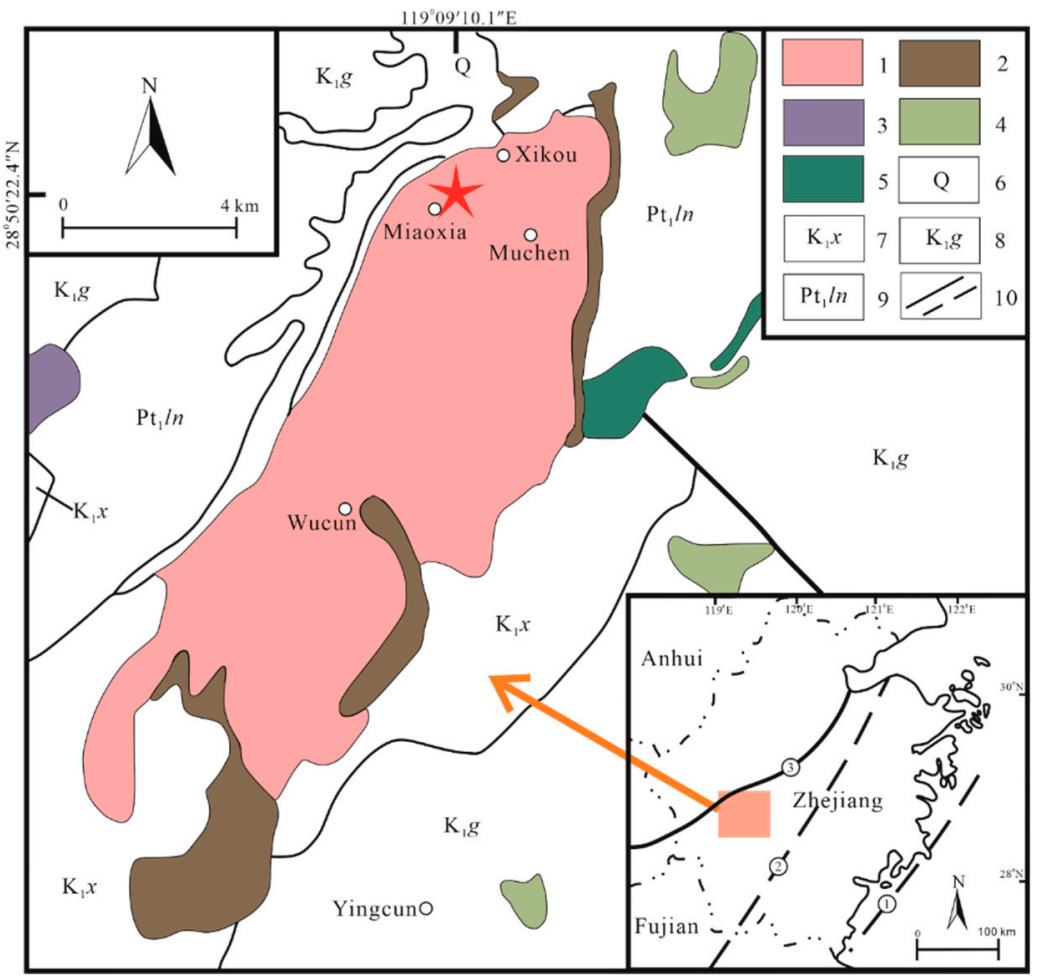

Figure 2. Simplified geological map of Muchen pluton (Modified after Liu et al. [30]). 1. Quartz monzonite; 2. Quartz syenite; 3. Quartz diorite; 4. Granite; 5. Late Yanshanian rhyolite porphyry; 6. Quaternary system; 7. Xishantou Formation; 8. Gaowu Formation; 9.metamorphic rocks of the Longou Group; 10. Faults (1) Changle-Nan'ao fault; (2) Zhenghe-Dapu fault; (3) Jiangshan-Shaoxing fault).

The Muchen pluton is mainly quartz monzonite, which consists of plagioclase $(\sim 30 \%)$, alkali feldspar $(\sim 35 \%)$, quartz $(\sim 15 \%)$, biotite $(\sim 10 \%)$, hornblende $(\sim 5 \%)$ and minor accessory minerals such as zircon and apatite (Figure 3$)$. The main minerals in quartz monzonites are medium- to fine-grained in size. The oscillatory zones can be found in the euhedral to subhedral plagioclase. Anhedral alkali feldspars grow at the interstices of other minerals. Biotite and hornblende occur as euhedral to subhedral crystals. Some MMEs (mafic microgranular enclaves) were found in field. They usually show ellipse, strip shape in quartz monzonite (Figure 3b). The main minerals in MME are similar to host rocks, but the biotite and hornblendes contents are higher than those in the host rock. The size of the biotite, hornblendes in MMEs are about 100-200 $\mu \mathrm{m}$, quietly smaller than those from the quartz monazite (500-2000 $\mu \mathrm{m}$ ) (Figure 3g). 

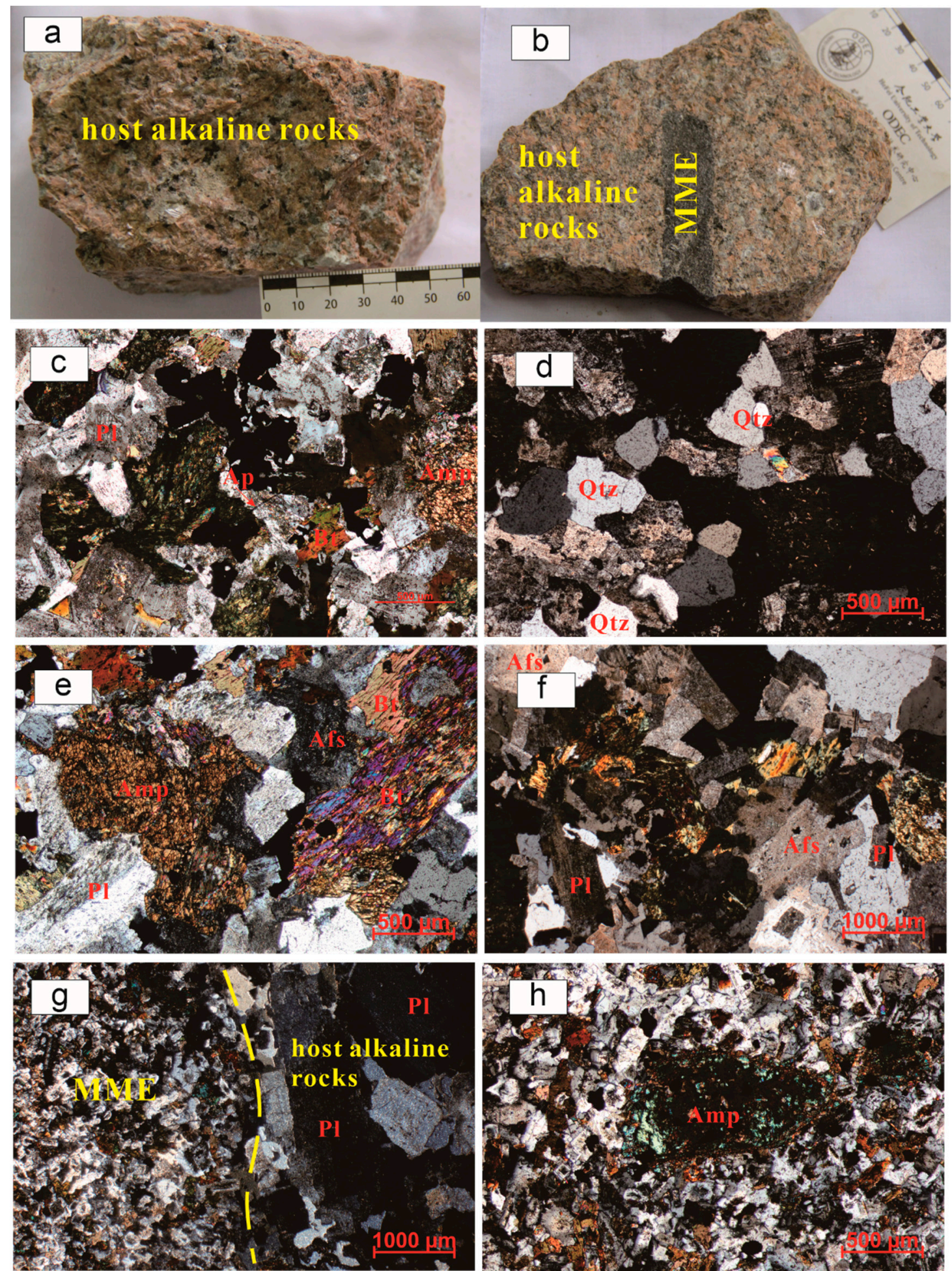

Figure 3. (a,b) Field photographs of quartz monzonite and MME (mafic microgranular enclave) in Muchen pluton; (c-f) are thin section photographs of the host quartz monzonite; ( $\mathbf{g})$ is the mineral assemblage between MME and host quartz monzonite; $(\mathbf{h})$ is the minerals assemblage of MME. All the thin section photographs (c,d) are cross-polarised light. ( $\mathrm{Pl}=$ plagioclase, Afs = alkali-feldspar, $\mathrm{Qtz}=$ quartz, $\mathrm{Bt}=$ biotite, $\mathrm{Amp}=$ amphibole, $\mathrm{Ap}=$ apatite). 


\section{Analytical Methods}

Nine representative fresh samples from the Muchen pluton were selected for petrographic observations, major and trace element, and $\mathrm{Sr}-\mathrm{Nd}-\mathrm{Pb}$ analysis. Zircon crystals were separated from the sample LY-8 for in situ U-Pb dating and subsequent $\mathrm{Hf}$ isotopic analysis.

\subsection{Zircon U-Pb Dating and Hf Isotope Analysis}

Zircon crystals were separated from a representative quartz monzonite (LY-8) by conventional techniques, including crushing, sieving, and magnetic and heavy liquid separation, and final hand picking under a binocular microscope. Zircon grains were then mounted in epoxy resin and polished to expose crystal centers. Prior to analysis, transmitted and reflected light photomicrographs and cathodoluminescence (CL) images were taken to reveal any internal zoning and inheritance, and to select target sites for $\mathrm{U}-\mathrm{Pb}$ dating and $\mathrm{Hf}$ isotope analyses. $\mathrm{CL}$ images of zircon grains were obtained using a Tescan MIRA3 LMH FESEM at Nanjing Hongchuang Exploration Technology Service Co., Ltd., Nanjing, China.

Zircon U-Pb isotopic analyses were conducted by laser ablation-inductively coupled plasma-mass spectrometry (LA-ICP-MS) at the Mineral Laboratory of the School of Resources and Environmental Engineering, Hefei University of Technology, Hefei China, using an Agilent 7900 ICP-MS Coupled to a Teledyne Cetac Technologies Analyte Excite laser-ablation system with a $193 \mathrm{~nm}$ ArF excimer laser. The ablated material was transported in helium carrier gas and combined with argon complemental gas prior to entering the plasma source of the ICP-MS. Analyses were carried out with a laser beam diameter of $30 \mu \mathrm{m}$ and repetition rate of $7 \mathrm{~Hz}$. Data acquisition for each analysis took $80 \mathrm{~s}(40 \mathrm{~s}$ on background; $40 \mathrm{~s}$ on signal). Offline processing of data includes selection of background signal, correction of sensitivity drift and analysis of major and trace element concentration through ICP-MS DataCal [44]. Detailed data processing methods are described in the literature [45,46]. A homogeneous standard zircon (GEMOC GJ-1; ${ }^{207} \mathrm{~Pb} / 206 \mathrm{~Pb}$ age of $608.5 \pm 1.5 \mathrm{Ma}$; [47]) was used to correct for the mass discrimination of the mass spectrometer and any elemental fractionation. A near-concordant standard zircon, $91500(1065 \mathrm{Ma})$, was used as an internal standard to assess the reproducibility and instrument stability. The U-Th-Pb isotope ratio of zircon 91500 is recommended by Wiedenbeck [48]. Mean age calculations and plotting of Concordia diagrams were performed using Isoplot/Ex_ver3.0 [49].

Hafnium isotopic compositions of zircon were measured by the LA-MC-ICP-MS at the Isotope Laboratory at the School of Resources and Environmental Engineering, Hefei University of Technology. A Teledyne Cetac Technologies Analyte Excite laser-ablation system and Thermofisher Neptune Plus MC-ICP-MS were combined for the experiments. A $193 \mathrm{~nm}$ ArF excimer laser was focused on the zircon surface with fluence of $\sim 3.0 \mathrm{~J} \mathrm{~cm}^{-2}$. Ablation protocol employed a spot diameter of $55 \mu \mathrm{m}$ at an $8 \mathrm{~Hz}$ repetition rate for $30 \mathrm{~s}$ (equating to 240 pulses). A mix gas of helium $(\sim 0.9 \mathrm{~L} / \mathrm{min})$ and argon $(\sim 0.9 \mathrm{~L} / \mathrm{min})$ was applied as the carrier gas to transport the aerosol to the MC-ICP-MS. Standard zircons (including Qinghu, Plešovice, and Penglai) were treated as quality control during the analytical process. All the data were reduced off-line with LAZrnHf-Calculator@HFUT [50]. Analytical results of ${ }^{176} \mathrm{Hf} /{ }^{177} \mathrm{Hf}$ ratios for the three standard zircons Penglai, Plešovice and Qinghu measured in one batch experiment are $0.282915 \pm 0.000019,0.282484 \pm 0.000007$ and $0.282997 \pm 0.000009$, respectively, which agree very well with the reference values (reference ratios of ${ }^{176} \mathrm{Hf} /{ }^{177} \mathrm{Hf}$ for Penglai, Plešovice and Qinghu are $0.282906 \pm 0.000016,0.282482 \pm 0.000013$ and $0.282996 \pm 0.000044$, respectively; [51-53]. The long-term monitoring of standard zircons initial ${ }^{176} \mathrm{Hf} /{ }^{177} \mathrm{Hf}$ values were calculated based on a Lu decay constant of $1.865 \mathrm{E}^{-11}$ [54]. The model ages were calculated under the assumption that the ${ }^{176} \mathrm{Lu} /{ }^{177} \mathrm{Hf}$ of average crust is 0.015 , and the ${ }^{176} \mathrm{Hf} /{ }^{177} \mathrm{Hf}$ and ${ }^{176} \mathrm{Lu} /{ }^{177} \mathrm{Hf}$ ratios of chondrite and depleted mantle at present are, respectively, 0.282772 and 0.0332 , and 0.28325 and 0.0384 [55]. 


\subsection{Whole-Rock Elemental and Sr-Nd-Pb Isotope Analysis}

Whole-rock major and trace element analyses were performed at Guizhou Tongwei Analytical Technology Co., Ltd. (Guiyang, China) using a Panalytical Axios PW4400 XRF and Thermal X series 2 (ICP-MS) equipped with a Cetac ASX-510 Autosampler. Instrument drift was corrected with internal spikes and external monitors. The ICP-MS procedure for trace element analysis follows the protocol of Eggins et al. [56] with modifications as described in Kamber et al. [57] and Li et al. [58].

For $\mathrm{Sr}-\mathrm{Nd}-\mathrm{Pb}$ isotope analysis $\sim 50-100 \mathrm{mg}$ of rock powder was dissolved with a mixture of concentrated nitric and hydrofluoric acid in bomb at $185^{\circ} \mathrm{C}$ in an oven for 3 days, and dried down on a hot plate at $80^{\circ} \mathrm{C}$. After converting any fluoride to nitrate, the dried residue was taken up with $3 \mathrm{~mL} 2 \mathrm{~N}$ nitric acid and passed through column chemistry to separate $\mathrm{Sr}, \mathrm{Pb}, \mathrm{Nd}$ from the matrix, using a modified procedure following [59-61]. Typical procedural blanks are ca. 65, 50, 60 pg for Sr, $\mathrm{Pb}, \mathrm{Nd}$, respectively.

Strontium isotopes were analyzed on a VG Sector 54 thermal ionization mass spectrometer system at University of Queensland, using a three-sequence dynamic procedure. Fractionation was corrected assuming ${ }^{86} \mathrm{Sr} /{ }^{88} \mathrm{Sr}$ ratio $=0.1194$. NBS-9987 was used as a monitor of instrument status. The standard NBS-987 was used during the run, in which the value $0.710252 \pm 0.000008(2 \sigma, n=4)$ for ${ }^{87} \mathrm{Sr} /{ }^{86} \mathrm{Sr}$ was obtained.

The $\mathrm{Nd}$ and $\mathrm{Pb}$ isotopes were analyzed on the $\mathrm{Nu}$ Plasma HR MC-ICP-MS at University of Queensland. Instrument bias and mass fractionation for $\mathrm{Nd}$ isotopes was corrected by normalizing raw ratios to ${ }^{146} \mathrm{Nd} /{ }^{144} \mathrm{Nd}=0.7219$. Standards $(\mathrm{W}-2 \mathrm{a}, \mathrm{BHVO})$ ) were measured during the run $(0.512533 \pm 0.000009,0,512,982 \pm 0.000007$, respectively $)$, which are within the range of recommended values (http://georem.mpch-mainz.gwdg.de/). All errors are $2 \sigma$. Instrument bias and mass fractionation for $\mathrm{Pb}$ isotope was corrected by $\mathrm{Tl}$, which with ${ }^{205} \mathrm{Tl} /{ }^{203} \mathrm{Tl}=0.23875$. BHVO2 in the same batch as the unknown samples, yielded average ratios, with $2 \sigma$ as below: ${ }^{208} \mathrm{~Pb} / 204 \mathrm{~Pb}=38.2464 \pm 24 ;{ }^{207} \mathrm{~Pb} /{ }^{204} \mathrm{~Pb}=$ $15.5385 \pm 9 ;{ }^{206} \mathrm{~Pb} /{ }^{204} \mathrm{~Pb}=18.6463 \pm 9$. The ratios were similar to the values from [62]

\section{Results}

\subsection{Zircon U-Pb Ages and Hf Isotopic Compositions}

Cathodoluminescence (CL) images from representative zircons from the Muchen quartz monzonite are shown in Figure 4. The results of LA-ICP-MS U-Pb isotopic analysis for this sample was listed in Supplementary S1 and shown in Figure 5. The Lu-Hf isotopic results are given in Supplementary S2.

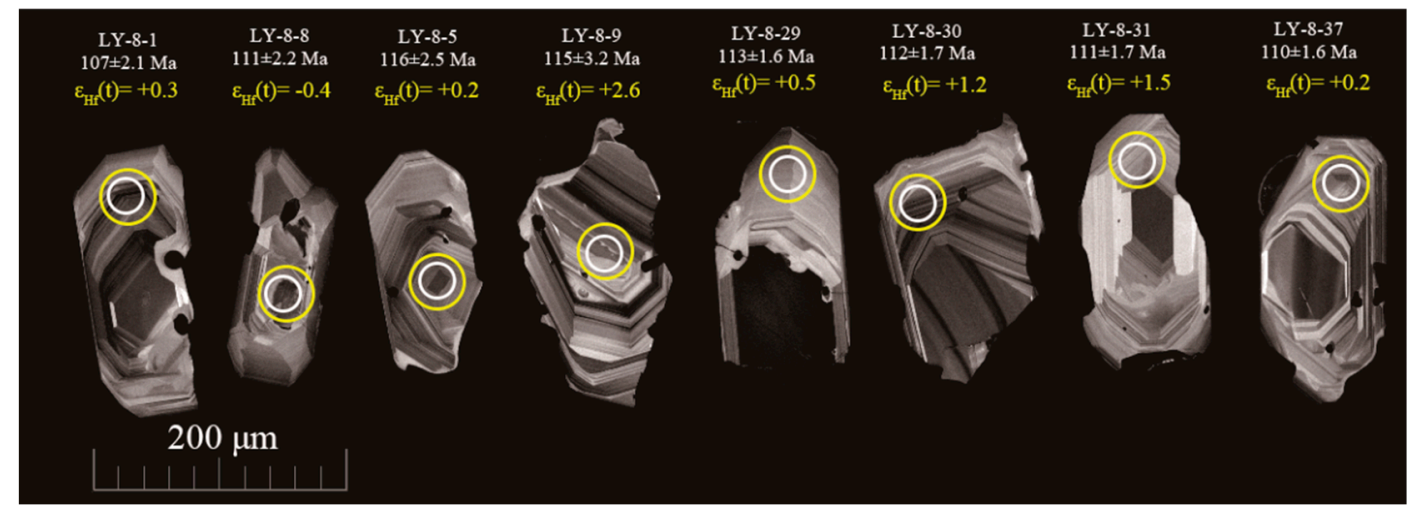

Figure 4. Cathodoluminescence (CL) images of selected zircon crystals from representative Muchen quartz monzonite and granite. The morphology of zircon grains, ${ }^{206} \mathrm{~Pb} /{ }^{238} \mathrm{U}$ ages, $\varepsilon_{\mathrm{Hf}}(\mathrm{t})$ values are shown. Small white spots indicate U-Pb dating positions of laser ablation-inductively coupled plasma-mass spectrometry (LA-ICP-MS), and large yellow spots indicate the sites of Hf isotope analyses of LA-MC-ICP-MS, with spot diameters showing the approximate laser spot sizes. 


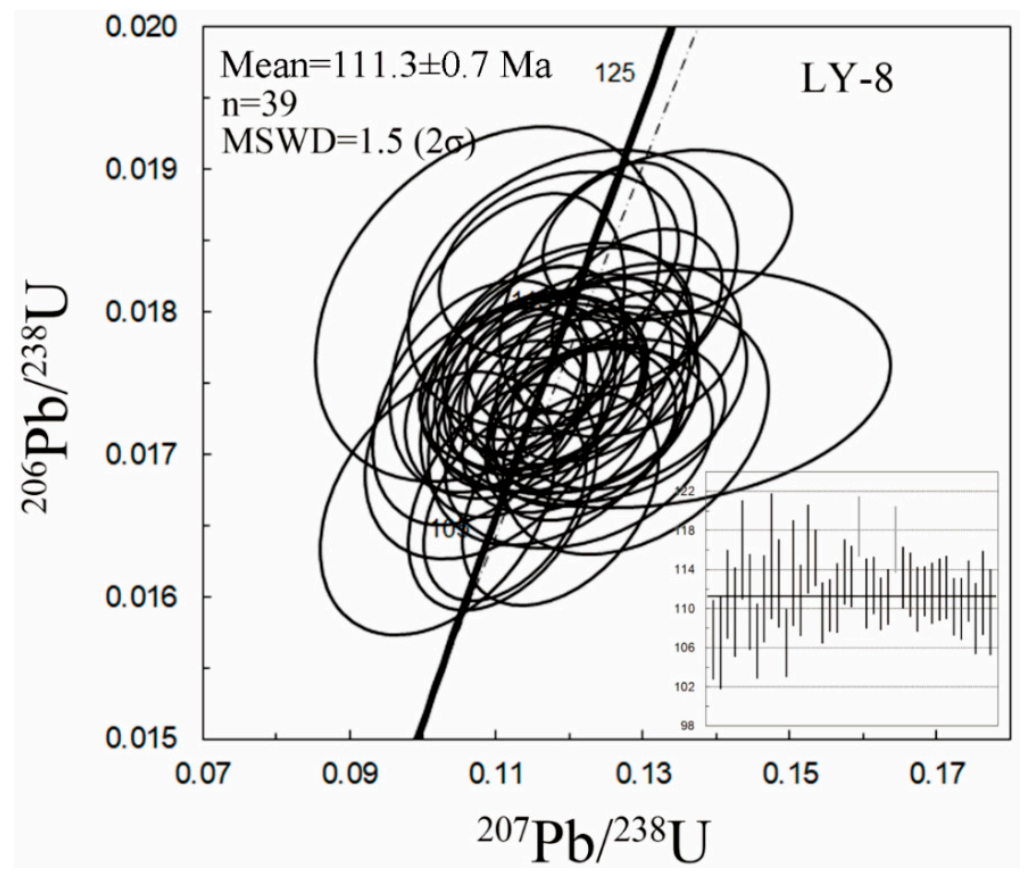

Figure 5. Zircon $\mathrm{U}-\mathrm{Pb}$ Concordia diagrams for representative quartz monzonite and granite from the Muchen pluton.

Zircon grains separated from quartz monzonite (LY-8) are euhedral and prismatic, and approximately 150-250 $\mu \mathrm{m}$ in length with length/width ratios of 1:1 to 3:1 and show well-developed oscillatory zoning in CL images (Figure 4). Thirty-nine U-Pb analyses show high Th/U ratios (0.53 to 1.16), indicating a magmatic origin for these zircons [63]. The ${ }^{206} \mathrm{~Pb} /{ }^{238} \mathrm{U}$ ages range from $106 \pm 2 \mathrm{Ma}$ (1 sigma) to $118 \pm 2 \mathrm{Ma}$ (1 sigma) with a weighted mean ${ }^{206} \mathrm{~Pb} /{ }^{238} \mathrm{U}$ age of $111.3 \pm 0.7 \mathrm{Ma}(\mathrm{MSWD}=1.5,2$ sigma; Figure 5), which consistent with previous study (112 Ma; [30]). These same zircon grains yielded a narrow range of initial ${ }^{176} \mathrm{Hf} /{ }^{177} \mathrm{Hf}$ values $(0.282655$ to 0.282778$)$ and $\varepsilon_{\mathrm{Hf}}(\mathrm{t})$ values $(-1.7$ to +2.6 ; Figure 6$)$, corresponding to two-stage $\mathrm{Hf}$ model ages $\left(\mathrm{T}_{\mathrm{DM} 2}(\mathrm{Hf})\right)$ of 1.00 to $1.28 \mathrm{Ga}$ (Supplementary $\mathrm{S} 2$ ).

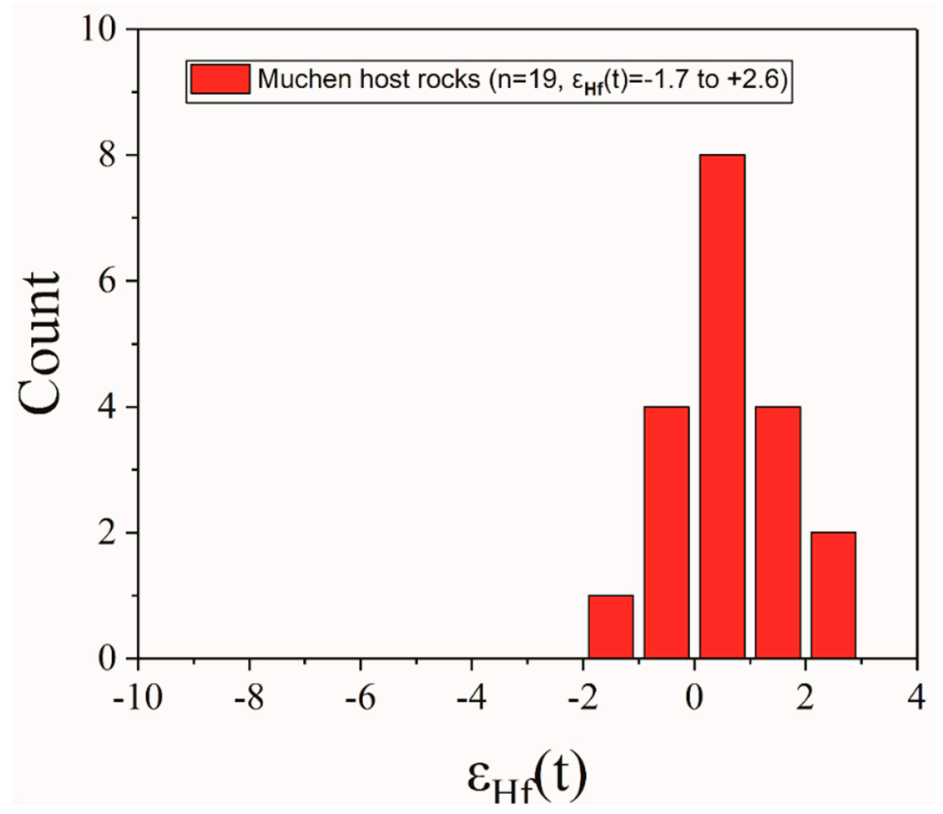

Figure 6. Histograms of $\varepsilon_{\mathrm{Hf}}(t)$ values for zircons from representative Muchen alkaline quartz monzonite. 


\subsection{Major and Trace Element Geochemistry}

Whole-rock major and trace element compositions for the Muchen pluton are given in Table 1. All the samples from the Muchen are silica-over-saturated rocks, containing quartz with various $\mathrm{SiO}_{2}(59.45$ to $68.61 \mathrm{wt} . \%$ ), and plot in the alkaline series field on a total alkali-silica (TAS) diagram (Figure 7a). The Muchen samples have moderately high alkali contents $\left(\mathrm{Na}_{2} \mathrm{O}+\mathrm{K}_{2} \mathrm{O}=8.64-10.46\right.$ wt. $\left.\%\right)$ and $\mathrm{K}$ contents $\left(\mathrm{K}_{2} \mathrm{O} / \mathrm{Na}_{2} \mathrm{O}=0.73-1.45\right.$, average 1.22; Figure 7b,c), similar to the shoshonites [64]. The Muchen samples are metaluminous $(\mathrm{A} / \mathrm{CNK}=0.89-1.04)$ to weakly peraluminous (Figure $7 \mathrm{~d})$. Although all the samples of the Muchen pluton have relatively lower $\mathrm{TFe}_{2} \mathrm{O}_{3} / \mathrm{MgO}$ ratios (3.77-9.06, average 5.98) than those of general A-type granites $\left(\mathrm{TFe}_{2} \mathrm{O}_{3} / \mathrm{MgO}=13.4 ;\right.$ [16]), the high $10,000 \mathrm{Ga} / \mathrm{Al}$ ratios, $\mathrm{Zr}+\mathrm{Nb}+\mathrm{Ce}+\mathrm{Y}$ and $\mathrm{Na}_{2} \mathrm{O}+\mathrm{K}_{2} \mathrm{O}$ contents suggests that Muchen pluton is A-type granitoids (Figure 8), which revises the conclusion of [30].
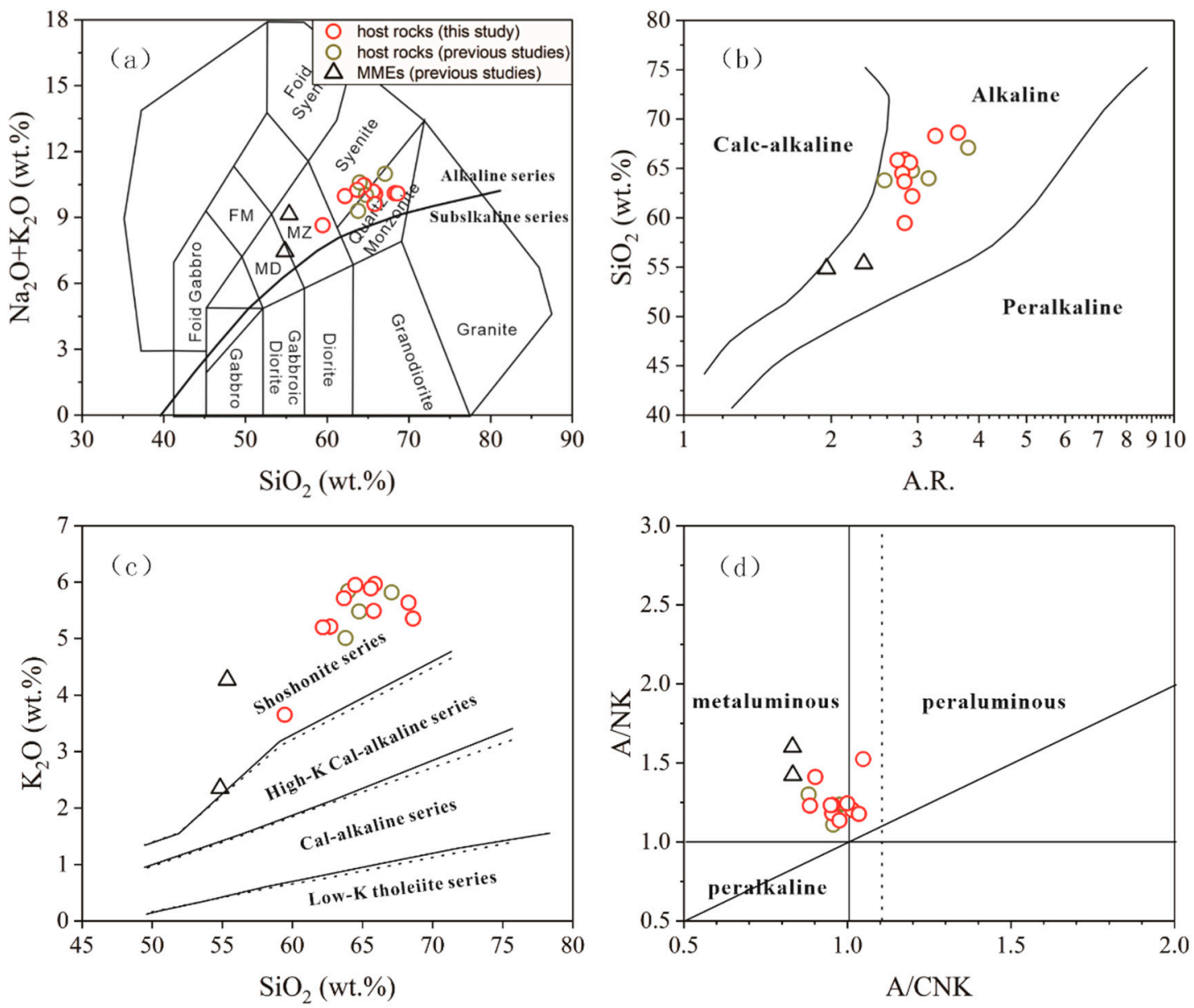

Figure 7. Chemical classification of rocks from the Muchen rocks. (a) Total alkali vs. silica (TAS) diagram [65]; with the thick solid line from Irvine and Baragar; [66]); (b) $\mathrm{SiO}_{2}$ vs. alkalinity ratio (A.R.) diagram [67]; (c) $\mathrm{K}_{2} \mathrm{O}$ vs. $\mathrm{SiO}_{2}$ diagram (solid lines from [68]; dashed lines from [69]); (d) A/NK vs. $\mathrm{A} / \mathrm{CNK}$ diagram [70,71]; Previous data of Muchen rocks from Liu et al. [30]. A/CNK $=\mathrm{Al}_{2} \mathrm{O}_{3} /(\mathrm{CaO}+$ $\mathrm{Na}_{2} \mathrm{O}+\mathrm{K}_{2} \mathrm{O}$ ) (with molar ratio), $\mathrm{A} / \mathrm{NK}=\mathrm{Al}_{2} \mathrm{O}_{3} /\left(\mathrm{Na}_{2} \mathrm{O}+\mathrm{K}_{2} \mathrm{O}\right.$ ) (with molar ratio).

All the samples are characterized by moderate to high REE contents (149-527 ppm) with lightly fractionated light rare earth elements (LREE; average $\left.(\mathrm{La} / \mathrm{Sm})_{\mathrm{N}}<6\right)$ and moderate heavy REE $(\mathrm{HREE})$ fractionation (average $\left.(\mathrm{La} / \mathrm{Yb})_{\mathrm{N}}=14.76\right)$. Chondrite-normalized REE patterns have a relatively steep slope with variable negative $\mathrm{Eu}$ anomalies $(\delta \mathrm{Eu}=0.22-0.75$, average 0.46 ; Figure $9 \mathrm{a})$. The samples are enriched in $\mathrm{Rb}$, Th, $\mathrm{U}, \mathrm{K}, \mathrm{Pb}, \mathrm{Zr}$, and $\mathrm{Hf}$ and marked depleted in $\mathrm{Nb}$, Ta, $\mathrm{Sr}, \mathrm{Ba}, \mathrm{P}$, and Ti (Figure 9b). 
Table 1. Chemical Composition of Muchen Pluton.

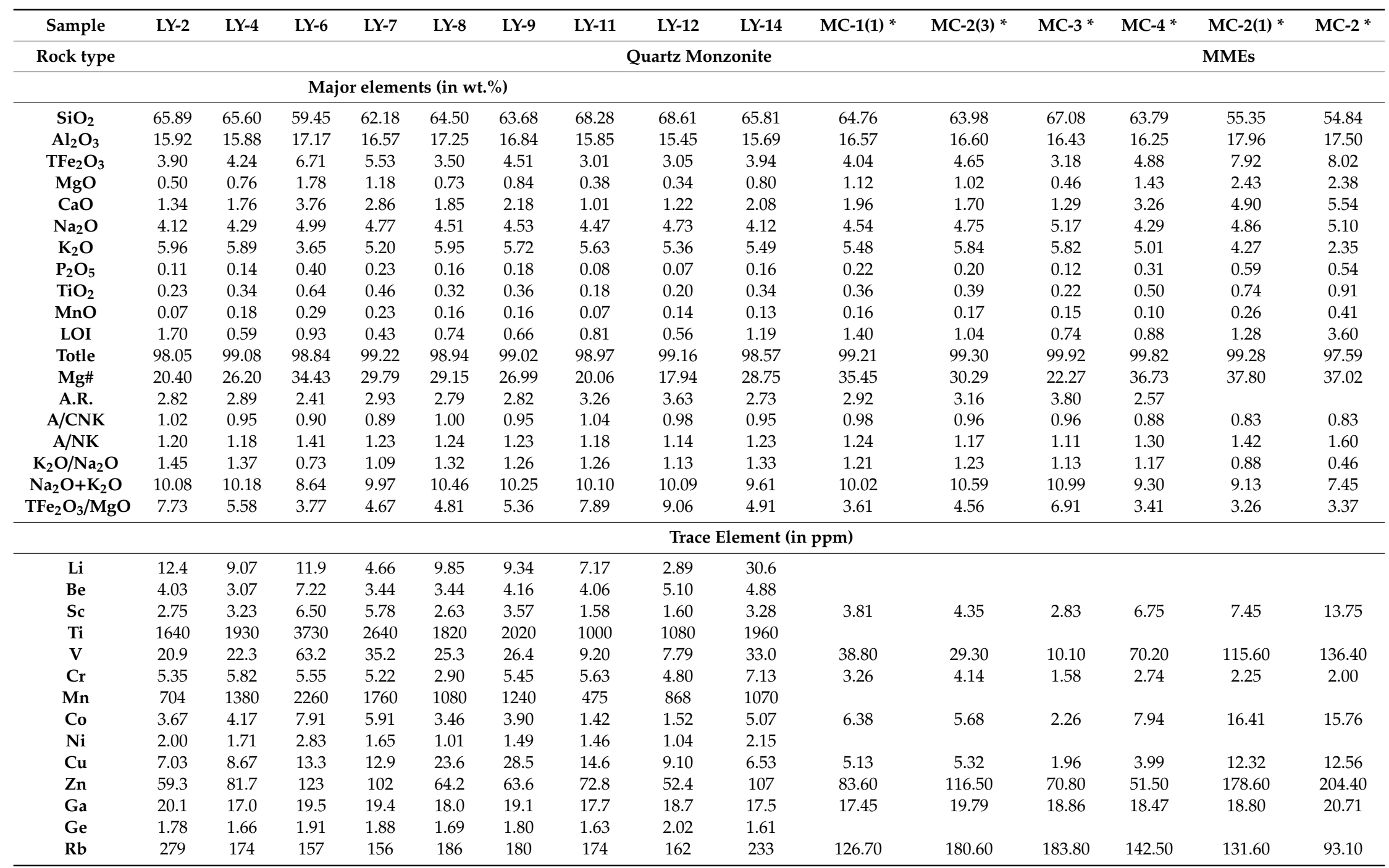


Table 1. Cont.

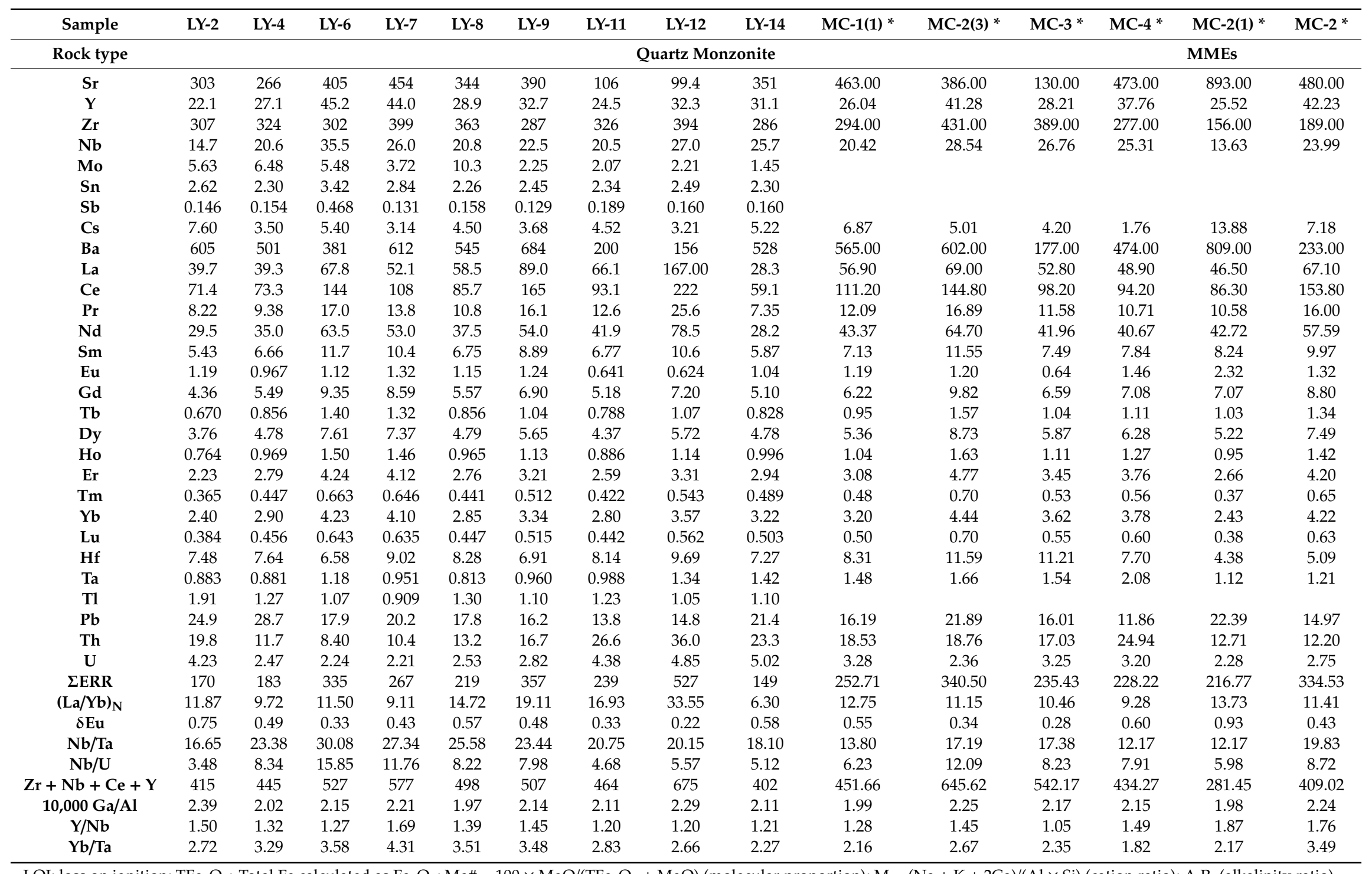

( $\left(\mathrm{Al}_{2} \mathrm{O}_{3}+\mathrm{CaO}+\mathrm{ALK}\right) /\left(\mathrm{Al}_{2} \mathrm{O}_{3}+\mathrm{CaO}-\mathrm{ALK}\right)(\mathrm{wt} . \%)$, ALK value is twice wt. $\%$ content of the $\mathrm{Na}_{2} \mathrm{O}$, when $\mathrm{SiO}_{2}>50 \mathrm{wt} . \%, 2.5>\mathrm{K}_{2} \mathrm{O} / \mathrm{Na}_{2} \mathrm{O}>1 ; \mathrm{A} / \mathrm{CNK}=\mathrm{Al} \mathrm{O}_{3} /\left[\mathrm{CaO}+\mathrm{Na} \mathrm{O}_{2} \mathrm{O}+\mathrm{K}_{2} \mathrm{O}\right]$ $(\mathrm{mol} \%) ; \mathrm{A} / \mathrm{NK}=\mathrm{Al}_{2} \mathrm{O}_{3} /\left[\mathrm{Na}_{2} \mathrm{O}+\mathrm{K}_{2} \mathrm{O}\right](\mathrm{mol} \%) ; \delta \mathrm{Eu}=2 \times \mathrm{Eu}_{\mathrm{N}} /\left(\mathrm{Sm}_{\mathrm{N}}+\mathrm{Gd}_{\mathrm{N}}\right)$. N is chondrite normalized. Data with * are from Liu et al. [30]. 

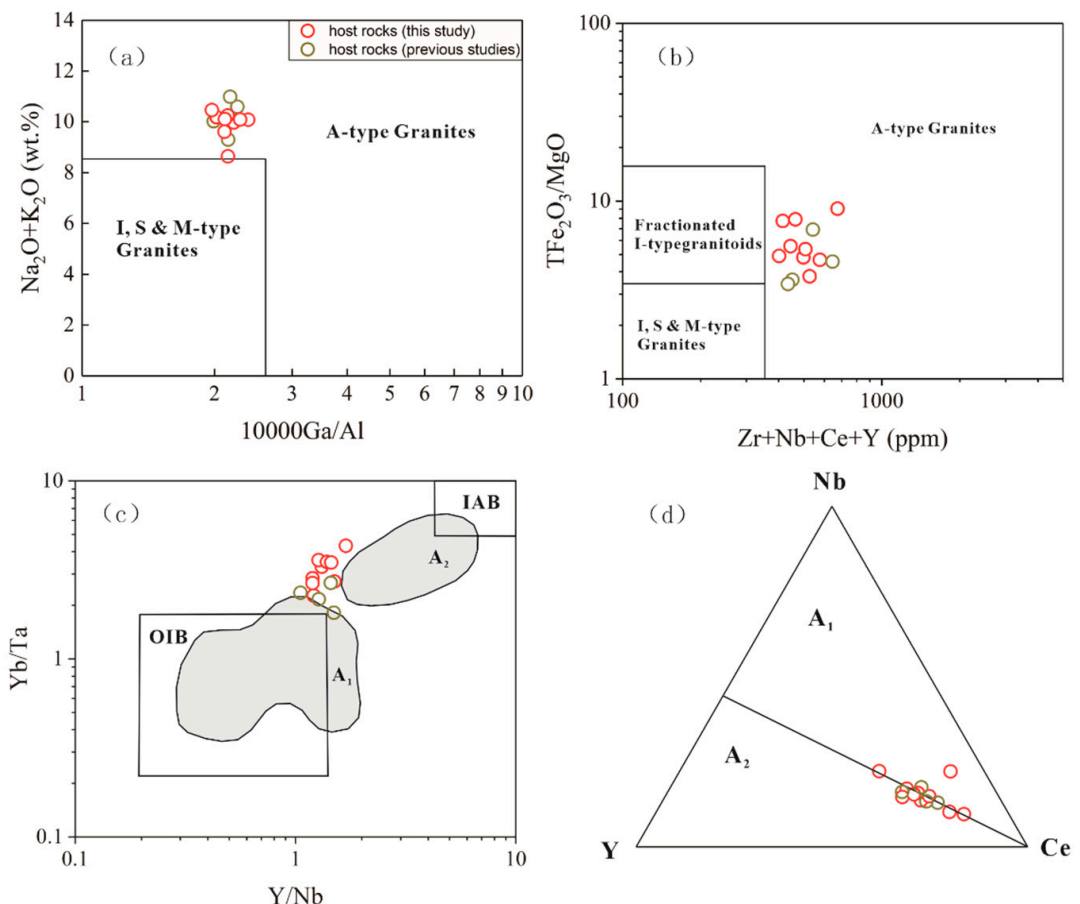

Figure 8. Chemical classification of rocks from the Muchen rocks. (a) $10,000 \mathrm{Ga} / \mathrm{Al}$ versus $\mathrm{Na}_{2} \mathrm{O}+$ $\mathrm{K}_{2} \mathrm{O}$ (wt.\%) diagram [16]. (b) $(\mathrm{Zr}+\mathrm{Nb}+\mathrm{Ce}+\mathrm{Y})(\mathrm{ppm})$ versus $\mathrm{TFe}_{2} \mathrm{O}_{3} / \mathrm{MgO}$ diagram [16]. (c) $\mathrm{Y} / \mathrm{Nb}$ versus $\mathrm{Yb} / \mathrm{Ta}$ diagram, gray fields represent $\mathrm{A}_{1}$ - and $\mathrm{A}_{2}$-type granites of [72]. (d) $\mathrm{Y}$-Ce-Nb diagram, dashed line corresponds to $\mathrm{Y} / \mathrm{Nb}$ ratio of 1.2 [73]. Previous data of Muchen rocks from Liu et al. [30].
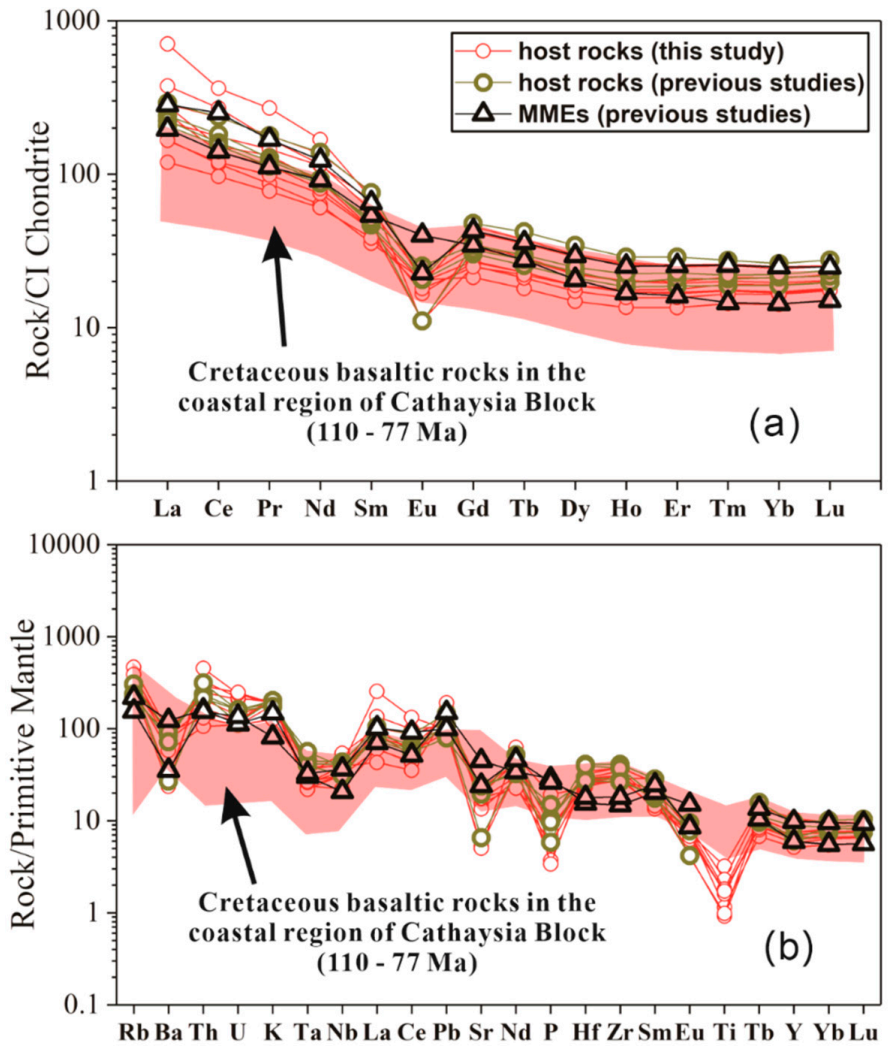

Figure 9. (a) Chondrite-normalized rare earth elements (REE, chondrite values are from Sun and McDonough. [74] and (b) primitive-mantle-normalized multi-element patterns (Primitive values are from McDonougha and Sun. [75] for Muchen rocks. Cretaceous basaltic rocks in the coastal region of Cathaysia Block are from Chen et al. [76] and Meng et al. [77]. Previous data of Muchen rocks are from Liu et al. [30]. 


\section{3. $\mathrm{Sr}-\mathrm{Nd}-\mathrm{Pb}$ Isotopic Composition}

The whole-rock $\mathrm{Sr}-\mathrm{Nd}-\mathrm{Pb}$ isotopic data are given in Tables 2 and 3. Initial ratios of isotopes $\left(\left({ }^{87} \mathrm{Sr} /{ }^{86} \mathrm{Sr}\right)_{i},\left({ }^{206} \mathrm{~Pb} /{ }^{204} \mathrm{~Pb}\right)_{i},\left({ }^{207} \mathrm{~Pb} /{ }^{204} \mathrm{~Pb}\right)_{i},\left({ }^{208} \mathrm{~Pb} /{ }^{204} \mathrm{~Pb}\right)_{i}\right.$ and $\left.\varepsilon_{\mathrm{Nd}}(t)\right)$ were calculated using the zircon $\mathrm{U}-\mathrm{Pb}$ age (111 Ma) obtained in this study.

The Muchen pluton has homogeneous $\left({ }^{87} \mathrm{Sr} /{ }^{86} \mathrm{Sr}\right)_{i}$ values $(0.7052$ to 0.7061$)$ and $\varepsilon_{\mathrm{Nd}}(t)$ values $(-2.6$ to -2.0$)$, and corresponding two-stage Hf model ages $\left(T_{\mathrm{DM} 2}\right)$ of $1.07-1.12 \mathrm{Ga}$. On the $\left({ }^{87} \mathrm{Sr} /{ }^{86} \mathrm{Sr}\right)_{i} \mathrm{vs}$. $\varepsilon_{\mathrm{Nd}}(t)$ diagram (Figure 10), all the samples plot near the chondritic uniform reservoir (CHUR) reference field. Lead isotope compositions are homogenous with $\left({ }^{206} \mathrm{~Pb} /{ }^{204} \mathrm{~Pb}\right)_{i}=18.11-18.30,\left({ }^{207} \mathrm{~Pb} /{ }^{204} \mathrm{~Pb}\right)_{i}$ $=15.59-15.60,\left({ }^{208} \mathrm{~Pb} /{ }^{204} \mathrm{~Pb}\right)_{i}=38.39-38.53$. All the samples show high radiogenic $\mathrm{Pb}$ isotopic ratios that plot to the right of the Geochron and above the Northern Hemisphere Reference Line (NHRL; Figure 11; [78]). In addition, they plot between the DM (Depleted Mantle) and EM (Enriched Mantle) end-members (Figure 11) [79].

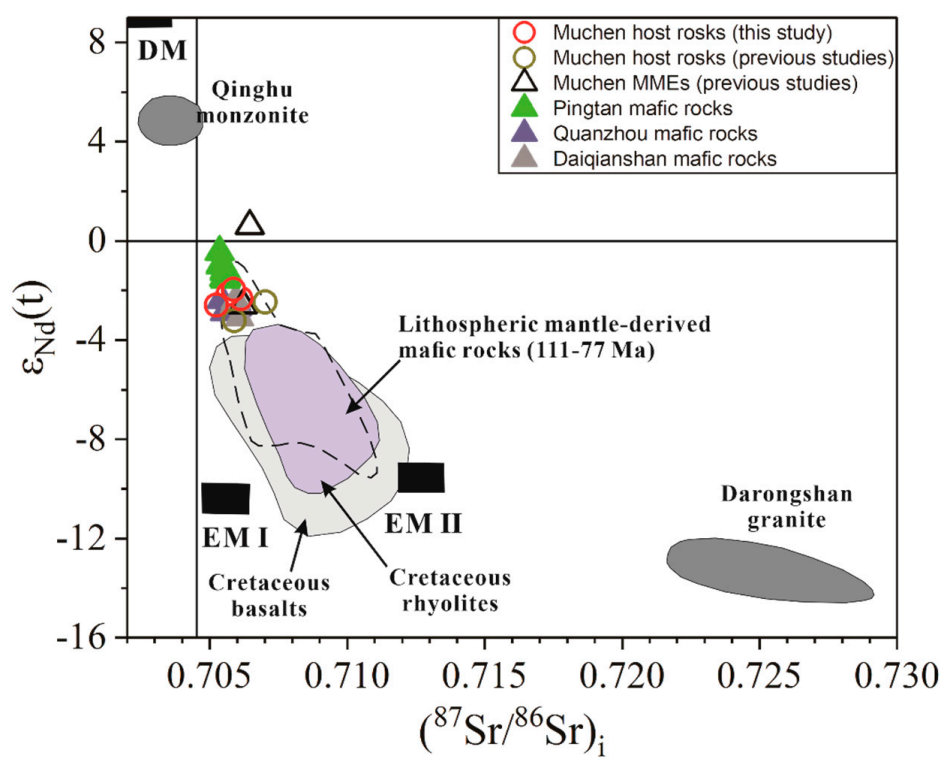

Figure 10. $\left({ }^{87} \mathrm{Sr} /{ }^{86} \mathrm{Sr}\right)_{i}$ versus $\varepsilon_{\mathrm{Nd}}(t)$ diagram for Muchen rocks. Data source: Previous data of Muchen rocks [30]; Pingtan mafic intrusion, Daiqianshan mafic intrusion and Quanzhou maific intrusion [79]; Darongshan granite [1]; Qinghu monzonite [80]; Cretaceous basalts and rhyolites [81-83]; Lithospheric mantle-derived mafic rocks (111-77 Ma) [76,77].
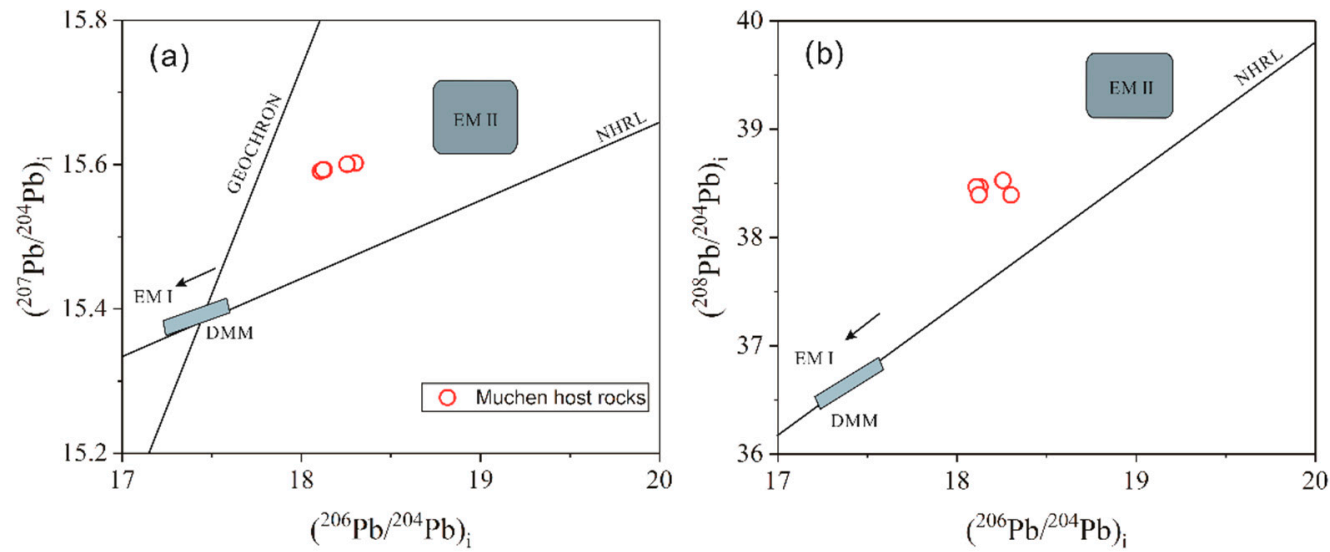

Figure 11. (a) ${ }^{207} \mathrm{~Pb} /{ }^{204} \mathrm{~Pb}(\mathrm{t})$ vs. ${ }^{206} \mathrm{~Pb} /{ }^{204} \mathrm{~Pb}(\mathrm{t})$ and $(\mathbf{b}){ }^{208} \mathrm{~Pb} / 204 \mathrm{~Pb}(\mathrm{t})$ vs. ${ }^{206} \mathrm{~Pb} /{ }^{204} \mathrm{~Pb}(\mathrm{t})$ of Muchen rocks. The isotopic compositions of EMI, EMII and DMM are from Zindler and Hart [79], the Geochron line and NHRL (Northern Hemisphere Reference Line) are from Hart [78]. 
Table 2. Pb Isotopic Data for Muchen Pluton.

\begin{tabular}{|c|c|c|c|c|c|c|c|c|c|c|c|c|c|c|}
\hline $\begin{array}{c}\text { Sample } \\
\text { No. }\end{array}$ & Locality & Rock type & Th & U & $\mathbf{P b}$ & ${ }^{206} \mathrm{~Pb} /{ }^{204} \mathrm{~Pb}$ & $\pm 2 \sigma$ & ${ }^{207} \mathrm{~Pb} /{ }^{204} \mathrm{~Pb}$ & $\pm 2 \sigma$ & ${ }^{208} \mathrm{~Pb} /{ }^{204} \mathrm{~Pb}$ & $\pm 2 \sigma$ & $\left({ }^{206} \mathrm{~Pb} /{ }^{204} \mathrm{~Pb}\right)_{\mathrm{i}}$ & $\left({ }^{207} \mathrm{~Pb} /{ }^{204} \mathrm{~Pb}\right)_{\mathrm{i}}$ & $\left({ }^{208} \mathrm{~Pb} /{ }^{204} \mathrm{~Pb}\right)_{\mathrm{i}}$ \\
\hline LY-6 & Muchen & quartz monzonite & 8.40 & 2.24 & 17.9 & 18.1413 & 0.0008 & 15.5992 & 0.0008 & 38.6277 & 0.0022 & 18.13 & 15.59 & 38.47 \\
\hline LY-7 & Muchen & quartz monzonite & 10.4 & 2.21 & 20.2 & 18.1188 & 0.0007 & 15.5963 & 0.0008 & 38.6439 & 0.0022 & 18.11 & 15.59 & 38.47 \\
\hline LY-8 & Muchen & quartz monzonite & 13.2 & 2.53 & 17.8 & 18.1377 & 0.0010 & 15.6001 & 0.0009 & 38.6485 & 0.0024 & 18.12 & 15.59 & 38.39 \\
\hline LY-11 & Muchen & quartz monzonite & 26.6 & 4.38 & 13.8 & 18.3354 & 0.0009 & 15.6181 & 0.0008 & 39.0586 & 0.0023 & 18.30 & 15.60 & 38.39 \\
\hline LY-14 & Muchen & quartz monzonite & 23.3 & 5.02 & 21.4 & 18.2813 & 0.0009 & 15.6124 & 0.0009 & 38.9027 & 0.0036 & 18.26 & 15.60 & 38.53 \\
\hline
\end{tabular}

Table 3. Rb-Sr and Sm-Nd Isotopic Data for Muchen Pluton.

\begin{tabular}{|c|c|c|c|c|c|c|c|c|c|c|c|c|c|c|}
\hline $\begin{array}{c}\text { Sample } \\
\text { No. }\end{array}$ & Locality & Rock type & $\mathbf{R b}$ & $\mathrm{Sr}$ & ${ }^{87} \mathrm{Rb} /{ }^{86} \mathrm{Sr}$ & ${ }^{87} \mathrm{Sr} /{ }^{86} \mathrm{Sr}$ & $\left({ }^{87} \mathrm{Sr} /{ }^{86} \mathrm{Sr}\right)_{i}$ & $\mathrm{Sm}$ & $\mathrm{Nd}$ & ${ }^{147} \mathrm{Sm} /{ }^{144} \mathrm{Nd}$ & ${ }^{143} \mathrm{Nd} /{ }^{144} \mathrm{Nd}$ & $\varepsilon_{\mathrm{Nd}}(t)$ & $\mathrm{T}_{\mathrm{DM} 2}$ & Age \\
\hline & & & ppm & ppm & & & & ppm & ppm & & & & $\mathrm{Ga}$ & $\mathrm{Ma}$ \\
\hline LY-6 & Muchen & $\begin{array}{c}\text { quartz } \\
\text { monzonite }\end{array}$ & 157.0 & 405.0 & 1.08 & $\begin{array}{c}0.707844 \pm \\
0.000008\end{array}$ & 0.7061 & 11.7 & 63.5 & 0.1138 & $\begin{array}{c}0.512458 \pm \\
0.000009\end{array}$ & -2.3 & 1.10 & 111 \\
\hline LY-7 & Muchen & $\begin{array}{c}\text { quartz } \\
\text { monzonite }\end{array}$ & 156.0 & 454.0 & 0.96 & $\begin{array}{c}0.707209 \pm \\
0.000008\end{array}$ & 0.7057 & 10.4 & 53.0 & 0.1212 & $\begin{array}{c}0.512474 \pm \\
0.000007\end{array}$ & -2.1 & 1.08 & 111 \\
\hline LY-8 & Muchen & $\begin{array}{c}\text { quartz } \\
\text { monzonite }\end{array}$ & 186.0 & 344.0 & 1.51 & $\begin{array}{c}0.708055 \pm \\
0.000011\end{array}$ & 0.7057 & 6.75 & 37.5 & 0.1111 & $\begin{array}{c}0.512466 \pm \\
0.000008\end{array}$ & -2.1 & 1.08 & 111 \\
\hline LY-11 & Muchen & $\begin{array}{c}\text { quartz } \\
\text { monzonite }\end{array}$ & 174.0 & 106.0 & 4.58 & $\begin{array}{c}0.712463 \pm \\
0.000013\end{array}$ & 0.7052 & 6.77 & 41.9 & 0.0998 & $\begin{array}{c}0.512435 \pm \\
0.000008\end{array}$ & -2.6 & 1.12 & 111 \\
\hline LY-14 & Muchen & $\begin{array}{c}\text { quartz } \\
\text { monzonite }\end{array}$ & 233.0 & 351.0 & 1.85 & $\begin{array}{c}0.708788 \pm \\
0.000009\end{array}$ & 0.7059 & 5.87 & 28.2 & 0.1285 & $\begin{array}{c}0.512488 \pm \\
0.000010\end{array}$ & -2.0 & 1.07 & 111 \\
\hline$\underset{*}{\text { MC-1-1 }}$ & Muchen & $\begin{array}{c}\text { quartz } \\
\text { monzonite }\end{array}$ & 126.7 & 463.2 & 0.79 & $\begin{array}{c}0.708234 \pm \\
0.000006\end{array}$ & 0.7070 & 7.13 & 43.37 & 0.0993 & $\begin{array}{c}0.512442 \pm \\
0.000014\end{array}$ & -2.4 & 1.11 & 112 \\
\hline MC-4 * & Muchen & $\begin{array}{c}\text { quartz } \\
\text { monzonite }\end{array}$ & 142.5 & 472.6 & 0.87 & $\begin{array}{c}0.707230 \pm \\
0.000008\end{array}$ & 0.7058 & 7.84 & 40.67 & 0.1165 & $\begin{array}{c}0.512416 \pm \\
0.000011\end{array}$ & -3.2 & 1.17 & 112 \\
\hline$\underset{*}{\text { MC-2-1 }}$ & Muchen & MME & 131.6 & 892.8 & 0.43 & $\begin{array}{c}0.706889 \pm \\
0.000008\end{array}$ & 0.7062 & 8.24 & 42.72 & 0.1166 & $\begin{array}{c}0.512446 \pm \\
0.000003\end{array}$ & -2.6 & 1.12 & 112 \\
\hline MC-2 * & Muchen & MME & 93.1 & 480.3 & 0.56 & $\begin{array}{c}0.707353 \pm \\
0.000007\end{array}$ & 0.7065 & 9.97 & 57.59 & 0.1046 & $\begin{array}{c}0.512600 \pm \\
0.000009\end{array}$ & 0.6 & 0.86 & 112 \\
\hline
\end{tabular}

Note: $\varepsilon_{\mathrm{Nd}}(t)$ values are calculated by granitoid ages and based on ${ }^{147} \mathrm{Sm}$ decay constant of $6.54 \times 10^{-12}$, the ${ }^{143} \mathrm{Nd} / /^{144} \mathrm{Nd}$ and ${ }^{147} \mathrm{Sm} / /^{144} \mathrm{Nd}$ ratios of chondrite and depleted mantle at and $\mathrm{Nd}$ contents with following equation: ${ }^{87} \mathrm{Rb} /{ }^{86} \mathrm{Sr}=\left(\mathrm{Rb}^{*} 0.2783 / 86.909\right) /\left(\mathrm{Sr} \mathrm{Sr}^{*} 0.0986 / 85.90926\right) ;{ }^{147} \mathrm{Sm} /{ }^{144} \mathrm{Nd}=\left(\mathrm{Sm}^{*} 0.1500 / 146.9149\right) /\left(\mathrm{Nd}{ }^{*} 0.23798 / 143.9101\right)$. The isotopic abundance of $\mathrm{Rb}$, $\mathrm{Sr}, \mathrm{Sm}$ and Nd are from CIAAW (Commission on Isotopic Abundances and Atomic Weights; https://www.ciaaw.org/). $\mathrm{T}_{\mathrm{DM} 2}$ ages are calculated according to the two-stage model as presented by Wu et al. [85]. Data of* are from Liu et al. [30]. 


\section{Discussion}

\subsection{Magma Temperature}

Zircon saturation thermometry $\left(\mathrm{T}_{\mathrm{Zr}}\right.$; [86]) can provide a simple and robust means to estimate magma temperatures. Calculated zircon saturation temperatures of the Muchen quartz monzonite after Watson and Harrison [86] are 847 to $867^{\circ} \mathrm{C}$ (average $859^{\circ} \mathrm{C}$; Figure 12a). Meanwhile, Ti-in-zircon thermometer $\left(\mathrm{T}_{\text {Ti-in-Zircon }}\right.$ [87]) can also be used to estimate magma temperatures. Calculated zircon crystal temperatures of Muchen quartz monzonite after Watson et al. [87] are 612 to $708{ }^{\circ} \mathrm{C}$ (average $654^{\circ} \mathrm{C}$; Figure $\left.12 \mathrm{c}\right)$. The Ti-in-zircon temperatures $\left(\mathrm{T}_{\mathrm{Ti}}\right.$-in-Zircon $)$ are lower than zircon saturation thermometry $\left(\mathrm{T}_{\mathrm{Zr}}\right)$ for the Muchen quartz monzonite. This is consistent with previous studies [88] because that the Ti-in-zircon thermometer $\left(\mathrm{T}_{\mathrm{Ti} \text {-in-Zircon }}\right)$ records the crystallization temperature of zircon, and zircon saturation thermometry $\left(\mathrm{T}_{\mathrm{Zr}}\right)$ records the melt temperature in an early stage. However, the nearly over $200{ }^{\circ} \mathrm{C}$ difference in Muchen quartz monzonite is rare.
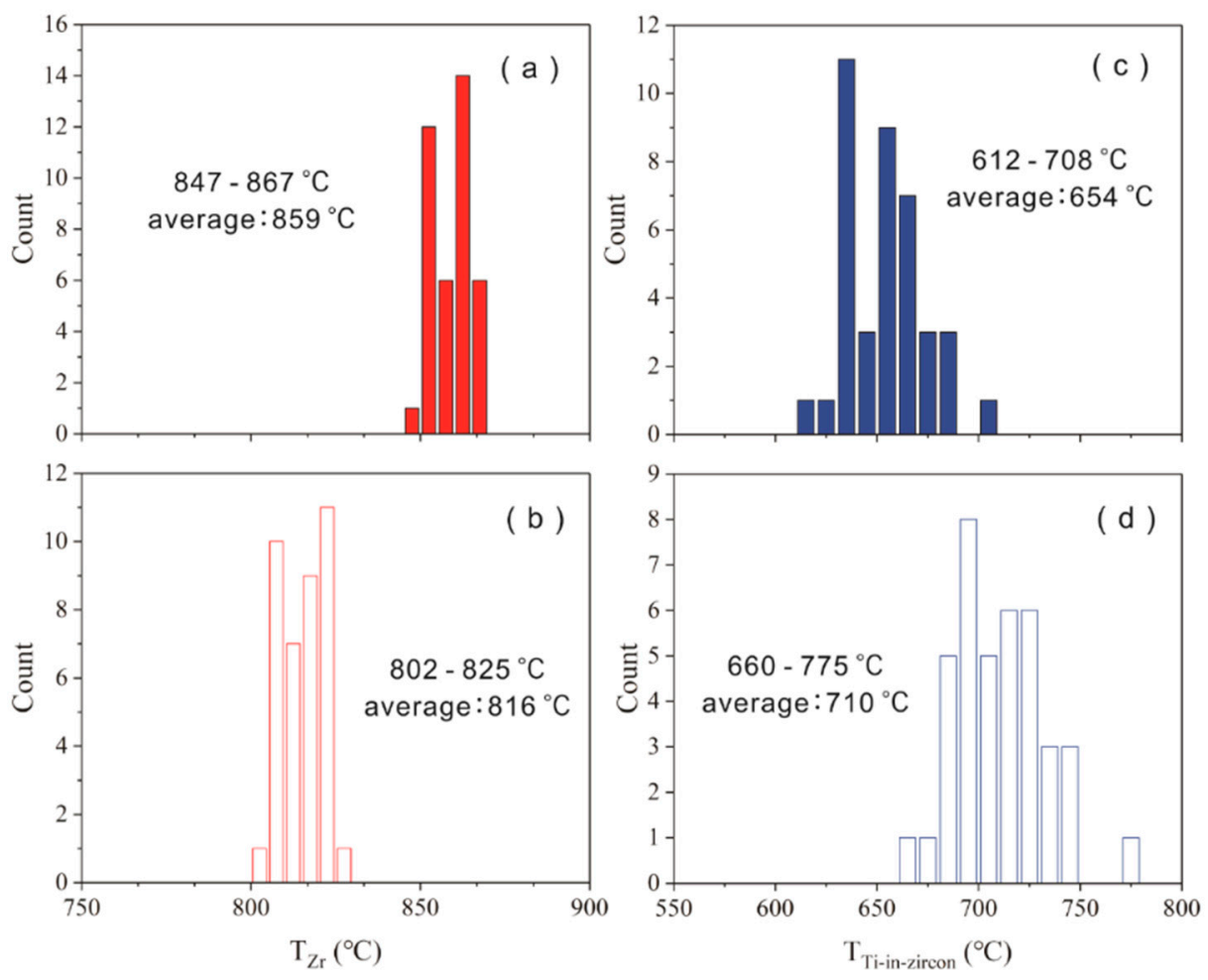

Figure 12. Histograms of zircon saturation thermometry $\left(\mathrm{T}_{\mathrm{Zr}}\right)$ and Ti-in-zircon thermometry $\left(\mathrm{T}_{\text {Ti-in-Zircon }}\right)$ for Muchen quartz monzonite (LY-8). (a) Calculated by Boehnke et al. [89]; (b) Calculated by Watson and Harrison. [86]; (c) Calculated by Watson et al. [87]. (d) Calculated by Ferry and Watson. [90].

Therefore, we re-calculate the magma temperature using the latest zircon saturation thermometry [89] and Ti-in-zircon thermometer [90]. The new calculated zircon saturation temperatures $\left(\mathrm{T}_{\mathrm{Zr}}\right)$ are 802 to $825{ }^{\circ} \mathrm{C}$ (average $816{ }^{\circ} \mathrm{C}$; Figure $12 \mathrm{~b}$ ) for the Muchen quartz monzonite. The latest Ti-in-zircon thermometer [90] is closely related with the activities of $\mathrm{SiO}_{2}$ (named $\alpha_{\mathrm{SiO}_{2}}$ in this paper) and $\mathrm{TiO}_{2}$ (named $\alpha_{\mathrm{TiO}_{2}}$ in this paper). Generally, the $\alpha_{\mathrm{SiO}_{2}}$ is $0.5 \sim 1.0$ in crustal rocks [91]. However, the presence of quartz suggests that the Muchen quartz monzonite was silica-saturated and would have $\alpha_{\mathrm{SiO}_{2}}$ of 1 . Similarly, the presence of zircon suggests that the $\alpha_{\mathrm{SiO}_{2}}$ value is greater than 0.5 [91]. Therefore, the new calculated Ti-in-zircon temperatures [90] for the Muchen quartz monzonite are at most 660 to $775{ }^{\circ} \mathrm{C}$ (average $710{ }^{\circ} \mathrm{C}$; Figure $12 \mathrm{~d}$ ), and the temperature might be overestimated by about 60 to $70{ }^{\circ} \mathrm{C}$ due to the variation of $\alpha_{\mathrm{TiO}_{2}}$. The obvious difference between zircon saturation temperature and Ti-in-zircon temperature for Muchen quartz monzonite is with over 
$\sim 100{ }^{\circ} \mathrm{C}$. The Ti-in-zircon thermometer is mainly affected by titanium content [91]. For the Muchen quartz monzonites, the titanium contents gradually decrease with the increasing $\mathrm{SiO}_{2}$ (Figure 13a), suggesting that the lower Ti-in-zircon temperature should be attributed to the crystal fractionation of titanium-rich minerals (such as Fe-Ti oxide), which results in the decrease of titanium content in zircons. Calculated Ti-in-zircon temperature for the Muchen quartz monzonite may record the late stage temperature of melt. Previous studies concluded that hydrous magma has low Ti-in-zircon temperatures ( $\mathrm{T}_{\mathrm{Ti} \text {-in-Zircon }}$ ) [6,92]. The existence of hydrous minerals (e.g., hornblende, biotite; Figure 3) suggests a water-rich environment in magma for the Muchen pluton. Therefore, the Ti-in-zircon thermometer is not robust relative to zircon saturation thermometry in the Muchen quartz monzonite. No correlation between zirconium and $\mathrm{SiO}_{2}$ content in the Muchen quartz monzonites (Figure 13b) also suggests that zircon saturation thermometry is more robust than Ti-in-zircon thermometer to estimate magma temperature of the Muchen quartz monzonite.
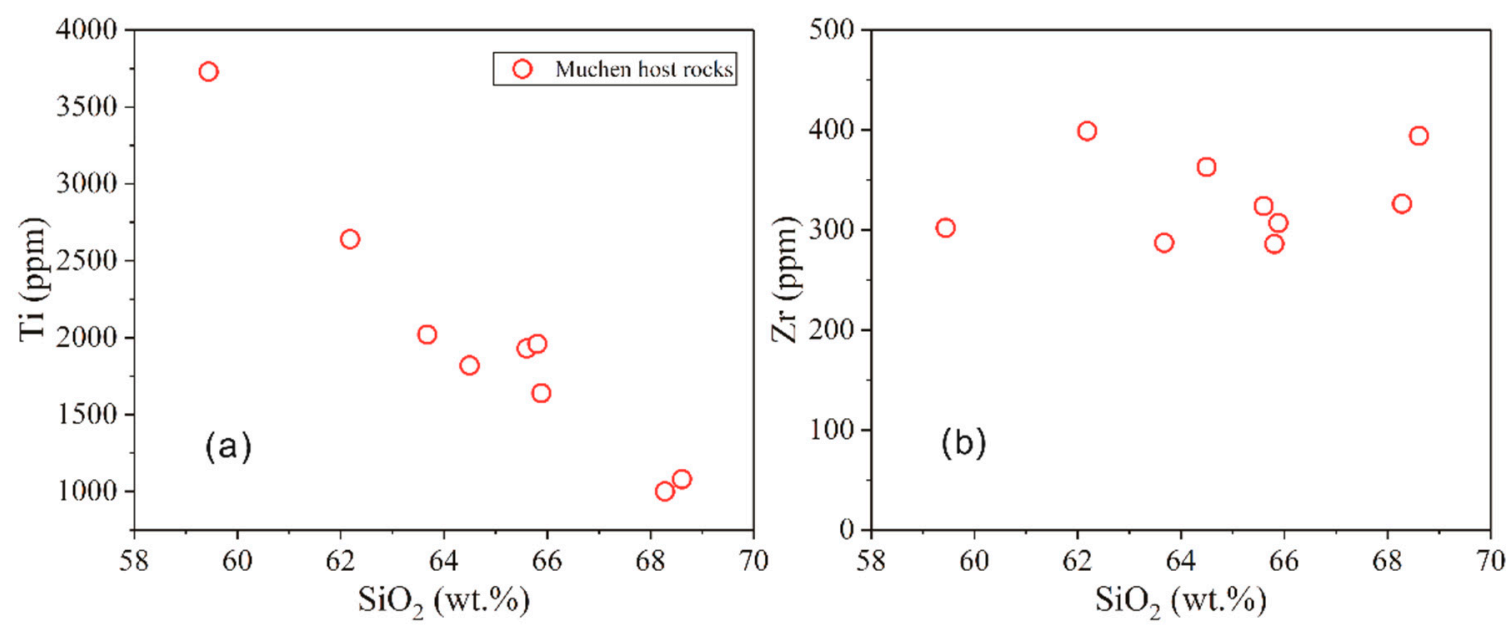

Figure 13. (a) $\mathrm{SiO}_{2}$ vs. $\mathrm{Ti}$ and (b) $\mathrm{SiO}_{2}$ vs. $\mathrm{Zr}$ diagrams for Muchen quartz monzonites.

In summary, we proposed that the zircon saturation temperatures (above $800{ }^{\circ} \mathrm{C}$; Figure $12 \mathrm{a}, \mathrm{b}$ ) can represent the melt temperature of the Muchen quartz monzonite, suggesting a high melting temperature in magma source.

\subsection{Magma Sources}

The homogenous Sr-Nd-Pb-Hf isotopic features (Figures 6, 10 and 11; Tables 2 and 3 and Supplementary S2) and uniform trace element patterns (Figure 9) indicate a stable origin for the Muchen pluton. All the samples of Muchen pluton have enriched $\mathrm{Sr}-\mathrm{Nd}$ and Lu-Hf isotopic compositions $\left(\left({ }^{87} \mathrm{Sr} /{ }^{86} \mathrm{Sr}\right)_{i}=0.7052-0.7061, \varepsilon_{\mathrm{Nd}}(t)=-2.6\right.$ to $-2.0, \varepsilon_{\mathrm{Hf}}(t)=-1.7$ to +2.6$)$ in this study, similar to previous study $\left(\left({ }^{87} \mathrm{Sr} /{ }^{86} \mathrm{Sr}\right)_{i}=0.7058-0.7070, \varepsilon_{\mathrm{Nd}}(t)=-3.3\right.$ to $-2.4, \varepsilon_{\mathrm{Hf}}(t)=-1.0$ to $\left.+1.8 ;[30]\right)$. Both Nd and $\mathrm{Hf}$ isotopes plot above the fields of $\mathrm{Nd}$ and $\mathrm{Hf}$ isotope evolutionary area for the Proterozoic crustal basement in the Cathaysia Block and close to the CHUR reference line (Figure 15), which preclude the involvement of crustal basement of Cathaysia Block, and suggests a significant mantle-derived contribution in the primary magma. 
In addition, the $\mathrm{Nb} / \mathrm{Ta}$ ratio also is a sensitive index for magma source due to follow reasons: (1) $\mathrm{Nb}$ and Ta have the same valency (+5) and very similar ionic radii $(69 \mathrm{pm}$ and $68 \mathrm{pm}$ for $\mathrm{Nb}$ and $\mathrm{Ta}$, respectively; [93]) and are not significantly fractionated by most geological processes; (2) $\mathrm{Nb} / \mathrm{Ta}$ ratios are generally constant during magmatic processes such as partial melting and fractional crystallization unless a significant volume of rutile and/or low-Mg-number amphibole is involved in the mantle source [12,94-99].

The Muchen quartz monzonites have much higher $\mathrm{Nb} / \mathrm{Ta}$ ratios (16.7 to 30.1, average 22.8) than those of continental crust (mean $\mathrm{Nb} / \mathrm{Ta}=13.4,16.5,8.3,12.4$ for upper crust, middle crust, lower crust and average crust, respectively; [100]), and primitive mantle $(\mathrm{Nb} / \mathrm{Ta}=17.65 ;[74])$. Partition coefficients for rutile/melt from both natural and experimental systems suggest that rutile is a potential phase to fractionate $\mathrm{Nb}$ from $\mathrm{Ta}$ and produce super-chondritic $\mathrm{Nb} /$ Ta ratios in the melt $[95,97,101]$. Batch melting calculations using an N-MORB (normal-type mid-oceanic ridge basalt) starting composition $(\mathrm{Nb}=2.33$, $\mathrm{Ta}=0.132, \mathrm{Nb} / \mathrm{Ta}=17.7 ;[74])$ and melt and phase proportions based on recent melting experiments [102] suggest that an increase in $\mathrm{Nb} / \mathrm{Ta}$ ratio to about 25 is possible with $\sim 1 \mathrm{wt}$ \% rutile in the residue phases [103]. Partial melting of amphibole-bearing peridotites could also produce melts with high $\mathrm{Nb} / \mathrm{Ta}$ ratios [101]. Therefore, the higher $\mathrm{Nb} / \mathrm{Ta}$ ratios may indicate the presence of residual rutile or amphibole in the source of the Muchen quartz monzonites. However, the correlations between $\mathrm{Rb} / \mathrm{Sr}$ and $\mathrm{Ba} / \mathrm{Rb}$ ratios preclude the presence of amphibole in the source of the Muchen quartz monzonites (Figure 14a). Thus, a rutile-rich source is proposed for Muchen quartz monzonites in this study. The high $\mathrm{Nb} / \mathrm{Ta}$ and moderate $\mathrm{Zr} / \mathrm{Hf}$ ratios in the Muchen rocks also favor a rutile-rich metasomatized mantle (Figure 14b; [97]). Moreover, the characteristics of $\mathrm{Rb} / \mathrm{Sr}$ and $\mathrm{Ba} / \mathrm{Rb}$ of Muchen quartz monzonites suggest a phlogopite-rich source (Figure 14a). Phlogopite is a K-rich mineral. The high potassic features of Muchen quartz monzonites $\left(\mathrm{K}_{2} \mathrm{O}=3.65 \sim 5.96 \mathrm{wt}\right.$ \% , average 5.45 wt.\%) may be derived from phlogopite. Stolz et al. [103] proposed that the mantle source of high potassic arc volcanic rocks, which have high $\mathrm{Nb} / \mathrm{Ta}$ value, was modified by silicic melts derived from the subducted slab, whereas for the low potassic arc rocks involved a slab-derived fluid. So, the high $\mathrm{Nb} / \mathrm{Ta}$ ratios of high potassic Muchen quartz monzonites may suggest a slab-derived melt metasomatized mantle. Similarly, Li et al. [12] proposed that the high Nb/Ta ratios (average 21.6) of the Late Mesozoic Jintonghu intrusive in SE China is also attributed to the modification of slab-derived fluid and melt by the subduction of the paleo-Pacific Plate. In addition, the low $\mathrm{Ba} / \mathrm{La}$ and high $\mathrm{Th} / \mathrm{Yb}$ ratios of Muchen quartz monzonites also favor a melt metasomatized mantle (Figure 14c; [104]). Ayers [105] suggested that fluids dehydrated from a subducted slab have very low $\mathrm{Nb} / \mathrm{U}$ ratios $(\sim 0.22)$ that reflect the transfer of significant amounts of large ion lithophile elements (LILEs), but not high field-strength elements (HFSEs), into the slab-derived fluids. Muchen quartz monzonites have variable Nb/U ratios (3.48 15.85, average 7.89$)$, with half $\mathrm{Nb} / \mathrm{U}$ ratios below 8.00 , especially for $\mathrm{LY}-2(\mathrm{Nb} / \mathrm{U}=3.48)$. Therefore, the source of Muchen quartz monzonites also included the slab-derived fluids. 

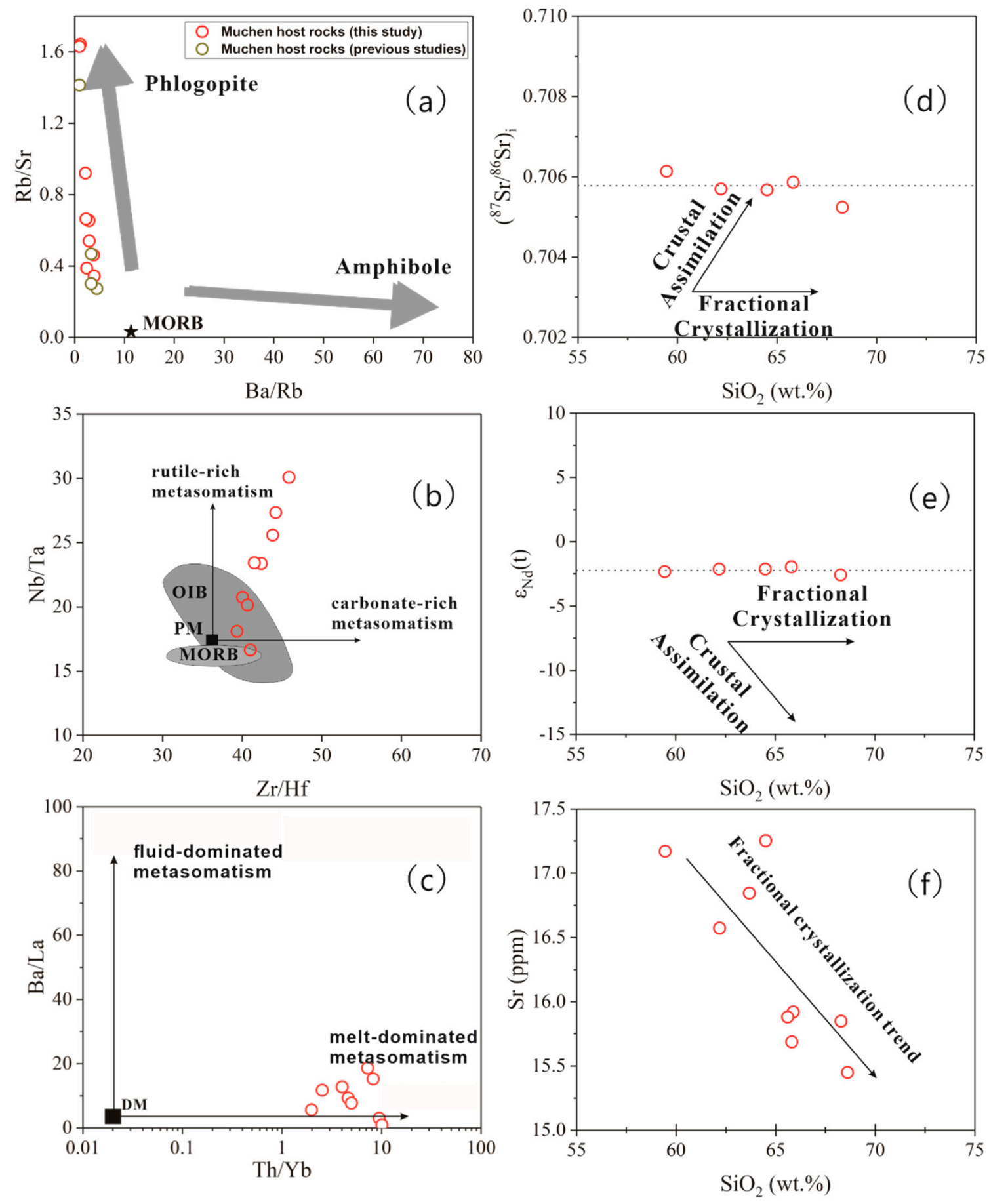

Figure 14. (a) $\mathrm{Rb} / \mathrm{Sr}$ vs. $\mathrm{Ba} / \mathrm{Rb}$; (b) $\mathrm{Zr} / \mathrm{Hf}$ vs. $\mathrm{Nb} / \mathrm{Ta}$ diagram (Guo et al., 2004); (c) Th/Yb vs. Ba/La diagram [104]; (d) $\mathrm{SiO}_{2}$ vs. $\left({ }^{87} \mathrm{Sr} /{ }^{86} \mathrm{Sr}\right)$; $\left(\right.$ e) $\mathrm{SiO}_{2}$ vs. $\varepsilon_{\mathrm{Nd}}$ (t); (f) $\mathrm{SiO}_{2}$ vs. Sr. Data source: Primitive Mantle (PM) and mid-oceanic ridge basalt (MORB) [74]; Ocean Island Basalt (OIB) [101,108]; Depleted Mantle (DM) [109]. Previous data of Muchen [30]. 


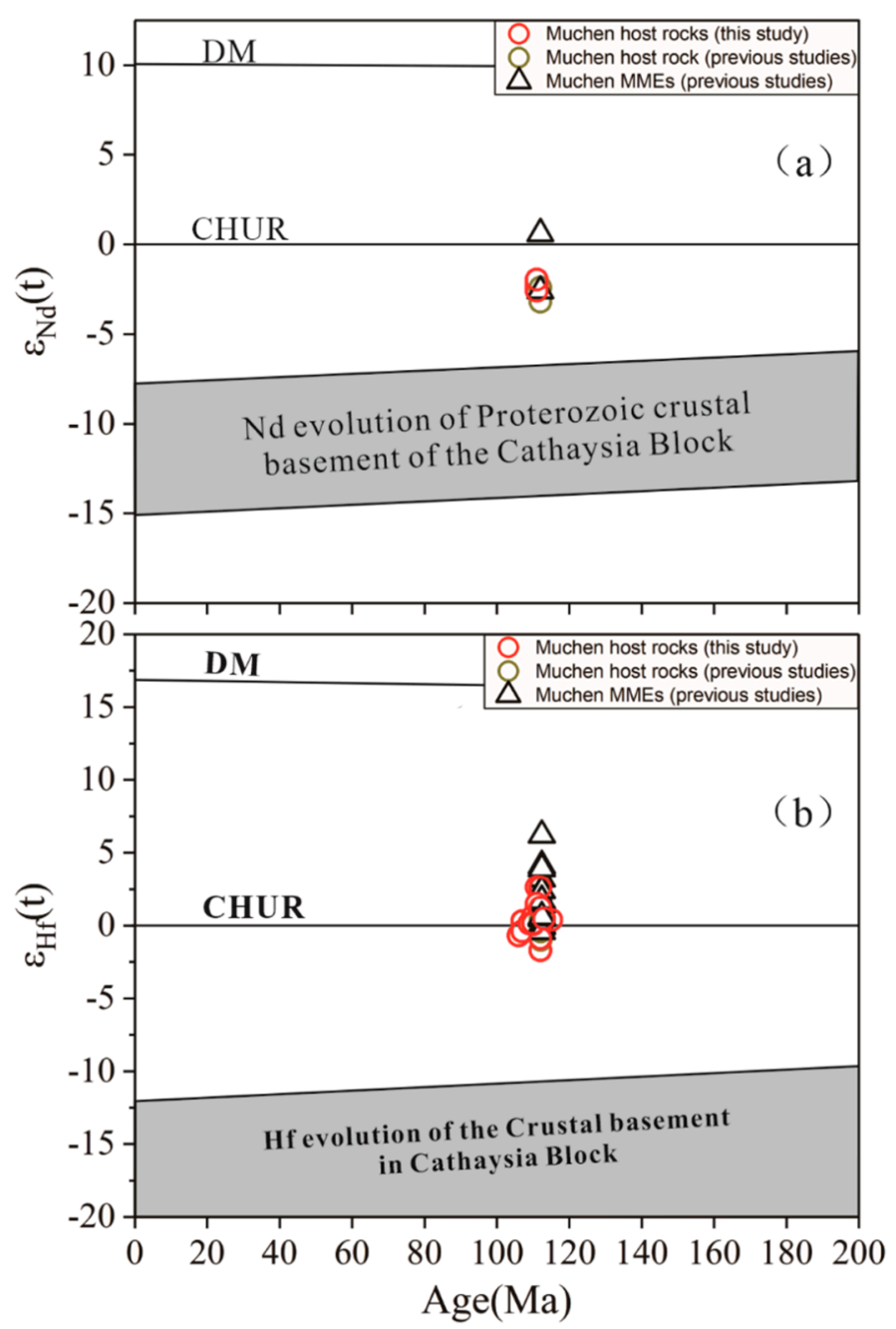

Figure 15. Nd and Hf isotope diagram of Muchen pluton. (a) The Nd isotope evolution for Cathaysia crustal basement are from Chen and Jahn [37]. (b) Hf isotope evolution for Cathaysia crustal basement are from Xu et al. [106] and He et al. [107]).

In summary, we propose that partial melting of enriched mantle metasomatized by slab-derived melt (mainly) and fluids produced the primary magma of Muchen pluton.

\subsection{Crustal Contamination and Fractional Crystallization}

Muchen quartz monzonites have constant $\mathrm{Sr}$ and $\mathrm{Nd}$ isotopic ratios $\left(\left({ }^{87} \mathrm{Sr} /{ }^{86} \mathrm{Sr}\right){ }_{i}\right.$ and $\varepsilon_{\mathrm{Nd}}(t)(0.7052$ to 0.7061 and -2.6 to -2.0 , respectively) with the increasing of $\mathrm{SiO}_{2}$ (59 69 wt.\%) (Figure 14d,e), which is inconsistent with crustal contamination. Here, we suggest that crustal contamination play a negligible role in the formation of the Muchen host quartz monzonites.

The systematic variation trends of major elements (Figure 16) and the subparallel REE patterns (Figure 9) indicate an important role of fractionation crystallization (FC) during magma evolution. The rapid decrease in $\mathrm{TFe}_{2} \mathrm{O}_{3}$ and increase in $\mathrm{SiO}_{2}$ with the decreasing $\mathrm{MgO}$ suggest that olivine is a major fractionated phase in the source for the Muchen quartz monzonites (Figure 16d,e). Pyroxene is also a significant fractionated phase causing positive correlations between $\mathrm{CaO}$ and $\mathrm{MgO}$ (Figure 16f). Crystal fractionation of plagioclase is also significant, as indicated by the negative correlations between $\mathrm{SiO}_{2}$ and $\mathrm{Al}_{2} \mathrm{O}_{3}$ and $\mathrm{Sr}$ (Figures $14 \mathrm{f}$ and 16a). Crystal fractionation of plagioclase would cause significant negative anomalies of Eu in granitoids and/or zircons. Thus, the obvious negative Eu anomalies in both the quartz monzonites $(\delta \mathrm{Eu}=0.22$ to 0.75 , average 0.48 ) and zircons $(\delta \mathrm{Eu}=0.01-0.22$, average $0.08)$ suggest significant fractionation of plagioclase. Fractionation of accessory minerals such as 
apatite and Fe-Ti oxides likely accounts for the negative correlations between $\mathrm{SiO}_{2}$ and $\mathrm{P}_{2} \mathrm{O}_{5}$ and $\mathrm{TiO}_{2}$ (Figure 16b,c). Therefore, fractionation of a mineral assemblage of olivine + pyroxene + plagioclase can roughly explain the chemical variation trends in the alkaline Muchen quartz monzonites.
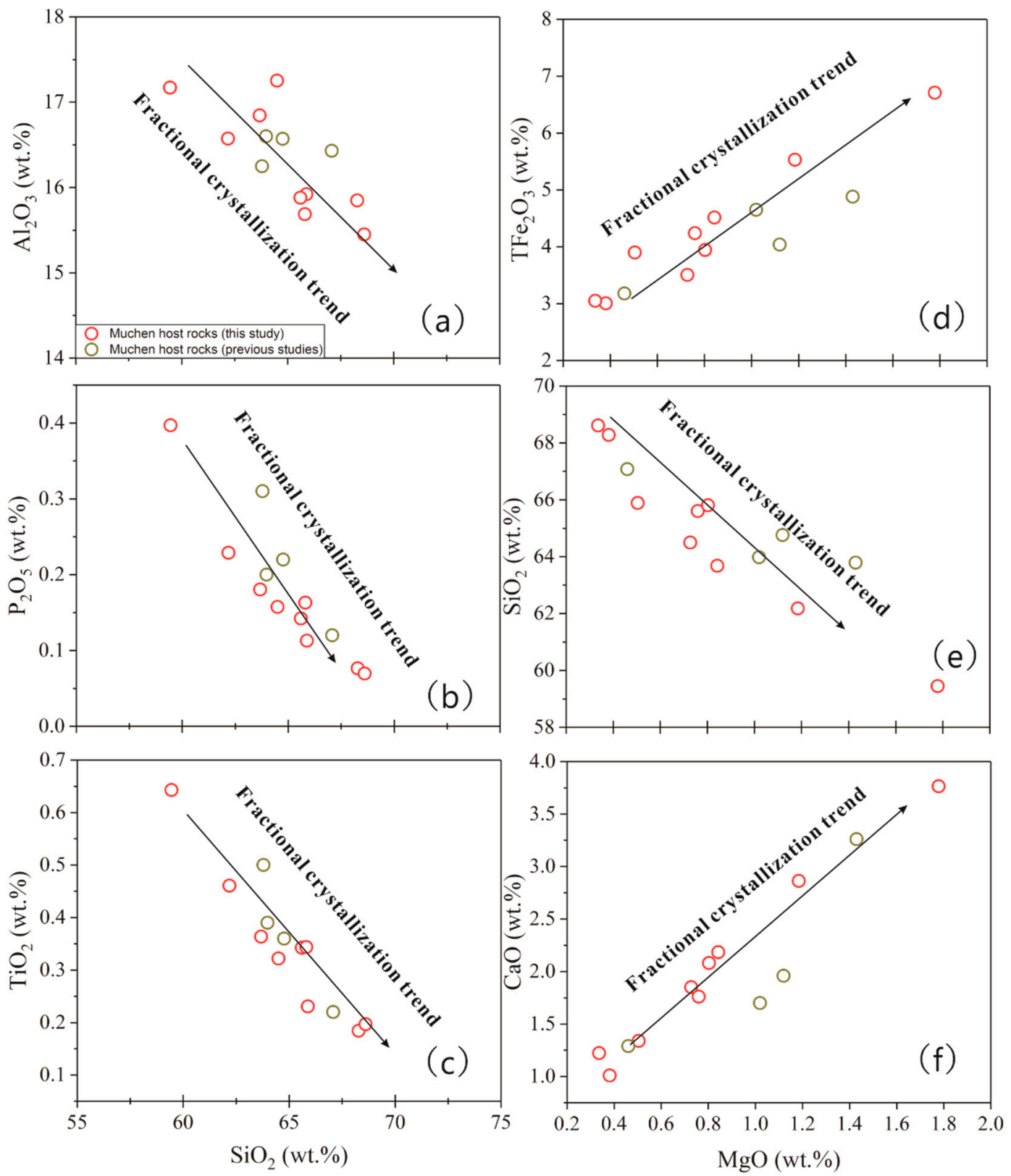

Figure 16. Bivariate plots of the Muchen alkaline rocks. Previous data of Muchen rocks are from [30]. The black arrow in figure $(\mathbf{a}-\mathbf{f})$ represents the fractional crystallization trend of Muchen magma.

\subsection{Petrogenesis}

In addition to host alkaline quartz monzonites, mafic microgranular enclaves (MMEs) also found in Muchen pluton (Figure 3). Liu et al., [30] proposed that Muchen quartz monzonites are derived from a hybrid magma produced by mixing between crustal materials and depleted mantle. In this study, we give a counter-argument that Muchen quartz monzonites are not formed by mixing between crustal-derived felsic magma and depleted mantle-derived mafic magma. We propose that MMEs are fragments of recrystallized or melt residues from the magma source, or early formed crystals from the host magma for follow reasons: (1) the geochemical features between the MMEs and host quartz 
monzonites are almost the same, e.g., same spider, REE and Sr-Nd-Hf isotopes (Figure 9; Table 1); (2) the high $\mathrm{K}$ contents, high temperatures (above $800^{\circ} \mathrm{C}$; Figure 12), and distinct but high $\mathrm{Nb} / \mathrm{Ta}$ ratios of the Muchen alkaline rocks are not simply explained by magma mixing between depleted mantle with continental crust melts.

Besides, Muchen alkaline quartz monzonites have similar Sr-Nd isotope signatures ( 111 Ma, $\left({ }^{87} \mathrm{Sr} /{ }^{86} \mathrm{Sr}\right)_{i}=0.7052-0.7061, \varepsilon_{\mathrm{Nd}}(t)=-2.6$ to -2.0$)$ with coeval mafic rocks from Pingtan $(\sim 116 \mathrm{Ma}$, $\left({ }^{87} \mathrm{Sr} /{ }^{86} \mathrm{Sr}\right)_{i}=0.7054-0.7056, \varepsilon_{\mathrm{Nd}}(t)=-0.4$ to -1.6$)$, Quanzhou $\left(\sim 113 \mathrm{Ma},\left({ }^{87} \mathrm{Sr} /{ }^{86} \mathrm{Sr}\right)_{i}=0.7054-0.7060\right.$, $\varepsilon_{\mathrm{Nd}}(t)=-2.9$ to -2.4$)$ and Daiqianshan $\left(\sim 113 \mathrm{Ma},\left({ }^{87} \mathrm{Sr} /{ }^{86} \mathrm{Sr}\right)_{i}=0.7059-0.7061, \varepsilon_{\mathrm{Nd}}(t)=-3.1\right.$ to -2.4$)$ in SE China $[6,104,110]$. These mafic rocks are formed via $5 \%-20 \%$ melting of a depleted mantle source metasomatized by the addition of $3 \%-5 \%$ subducted sediment-derived melt [104]. Therefore, partial melting of metasomatized mantle may be the real origin of Muchen alkaline rocks, with significant fractional crystallization of olivine + orthopyroxene + plagioclase. In addition, the high $\varepsilon_{\mathrm{Nd}}(t)$ value of MME (+0.6) suggests that a small proportion of mantle, which was not metasomatized by slab melts, may add to the primitive magma of Muchen pluton.

Normally, melts from the basaltic lower continental crust are characterized by low $\mathrm{Mg \#} \mathrm{values}$ $(<40)$ regardless of the degree of melting, whereas those with higher Mg\# values $(>40)$ can only be generated by the involvement with a mantle component [111]. However, the Muchen quartz monzonite has low Mg\# values (18 to 34, average 26; Table 1). Here, we proposed that the low Mg\# character of the Muchen quartz monzonite is a real case for the pressure effect of $\mathrm{Mg} \#$ for the following two reasons:

(1) Experimental petrology suggests that the pressure of melting is as important as source composition in generating an A-type melt [22]. The Mg\# values of A-type granitic magma was affected by pressures $(\mathrm{Mg \#}=35 \sim 42$ for $8 \mathrm{kbar}$ and $\mathrm{Mg \#} \mathrm{=} \mathrm{19} \mathrm{21} \mathrm{for} 4 \mathrm{kbar})$ [22].

(2) MELTs simulation: MELTs is a perfect tool to simulate the process of magmatic evolution in different pressure conditions (http://melts.ofm-research.org/) [112]. The Cretaceous mafic rocks in SE China [40] were chosen to simulate the crystal fractionation process in different pressures setting (8 3 kbar) using MELTs. These mafic rocks have similar $\mathrm{Sr}-\mathrm{Nd}$ isotopes $\left(\left({ }^{87} \mathrm{Sr} /{ }^{86} \mathrm{Sr}\right)_{i}=0.7053-0.7070\right.$, $\varepsilon_{\mathrm{Nd}}(\mathrm{t})=-3.8$ to -1.2$)$ to the Muchen alkaline quartz monzonite. The results confirm that mantle-derived magma could produce intermediate-acid magma with low $\mathrm{Mg \#}$ values $(<30)$ in relative low pressure ( $\leq 7 \mathrm{kbar}$ ) through crystallization of olivine, pyroxene, spinel and/or plagioclase (Figure 17; Supplementary S4). However, the magma could only evolve to low-silicic magma $\left(\mathrm{SiO}_{2}<60\right.$ wt.\%) with relatively high $\mathrm{Mg \#}$ values $(\mathrm{Mg \#} \mathrm{>42)}$ under 8 kbar pressure conditions (Figure 17; Supplementary S2). Therefore, the low Mg\# features of Muchen quartz monzonites ( $<30$ mostly) may be attributed to a low-pressure setting with the pressures below 7 kbar. Previous study also suggests that the rock-forming pressure of the Muchen pluton is low ( 0.2 GPa) [30].

In summary, the geochemical characteristics of the Muchen monzonites suggest that they were derived from partial melting of enriched metasomatized mantle in a low-pressure setting (see in detail in Section 5.5). 

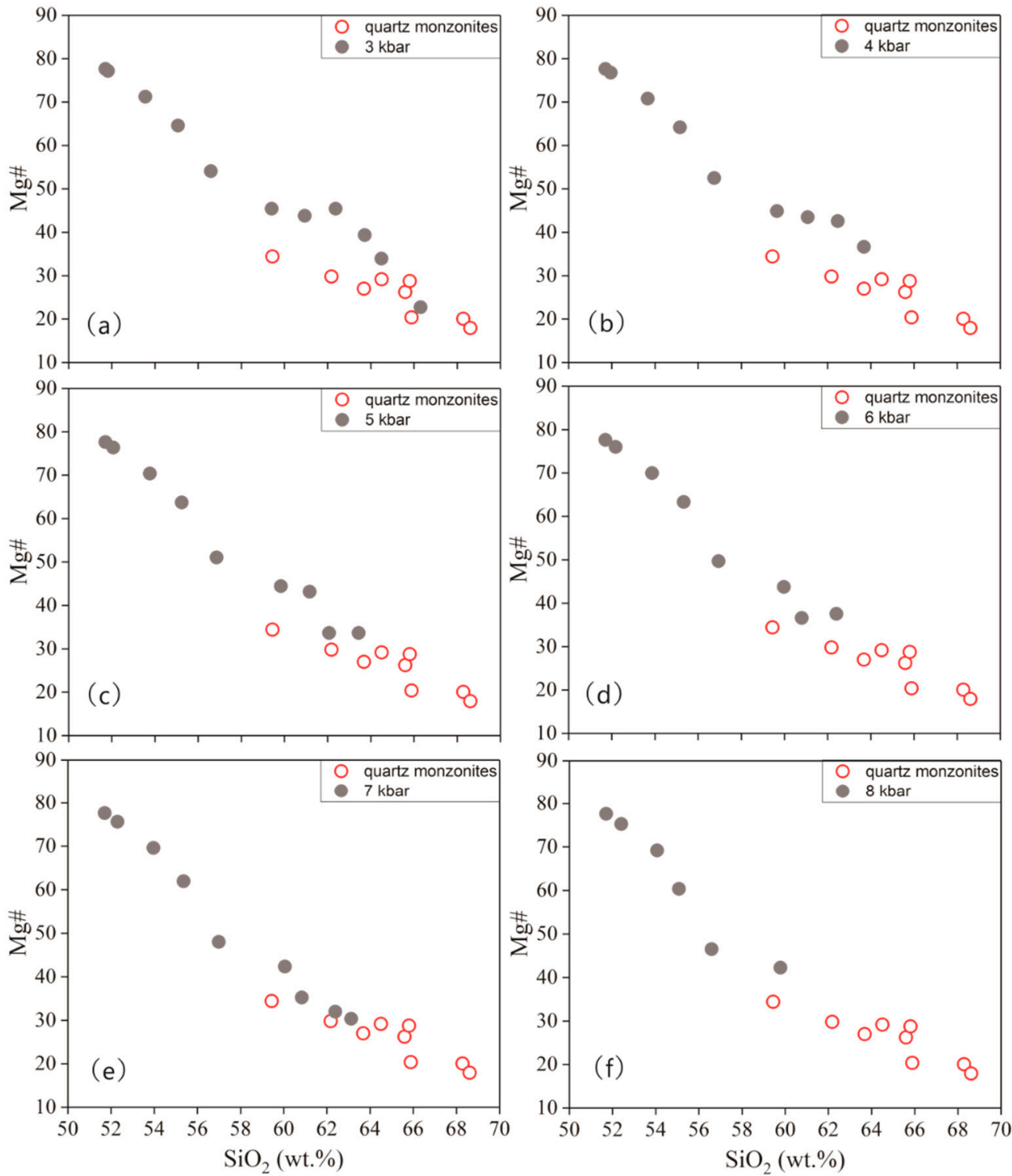

Figure 17. $\mathrm{SiO}_{2}$ vs. Mg\# diagram for Muchen quartz monzonites and simulative magma. (a-f) represent the simulate results in different temperature $(\mathrm{T})$ and pressure $(\mathrm{P})$ condition. $(\mathbf{a}): \mathrm{T}=3 \mathrm{kbar}$, and $\mathrm{T}=1500{ }^{\circ} \mathrm{C}, 1400{ }^{\circ} \mathrm{C}, 1300{ }^{\circ} \mathrm{C}, 1200{ }^{\circ} \mathrm{C}, 1100{ }^{\circ} \mathrm{C}, 1000{ }^{\circ} \mathrm{C}, 950{ }^{\circ} \mathrm{C}, 900{ }^{\circ} \mathrm{C}, 850{ }^{\circ} \mathrm{C}, 800{ }^{\circ} \mathrm{C}, 750{ }^{\circ} \mathrm{C}$; (b): $\mathrm{T}=4 \mathrm{kbar}$, and $\mathrm{T}=1500{ }^{\circ} \mathrm{C}, 1400^{\circ} \mathrm{C}, 1300^{\circ} \mathrm{C}, 1200{ }^{\circ} \mathrm{C}, 1100{ }^{\circ} \mathrm{C}, 1000^{\circ} \mathrm{C}, 950{ }^{\circ} \mathrm{C}, 900{ }^{\circ} \mathrm{C}, 850{ }^{\circ} \mathrm{C}$; (c): $\mathrm{T}=5 \mathrm{kbar}$, and $\mathrm{T}=1500{ }^{\circ} \mathrm{C}, 1400^{\circ} \mathrm{C}, 1300{ }^{\circ} \mathrm{C}, 1200{ }^{\circ} \mathrm{C}, 1100{ }^{\circ} \mathrm{C}, 1000^{\circ} \mathrm{C}, 950{ }^{\circ} \mathrm{C}, 900{ }^{\circ} \mathrm{C}, 850{ }^{\circ} \mathrm{C} ;(\mathrm{d}): \mathrm{T}$ $=6 \mathrm{kbar}$, and $\mathrm{T}=1500^{\circ} \mathrm{C}, 1400^{\circ} \mathrm{C}, 1300^{\circ} \mathrm{C}, 1200^{\circ} \mathrm{C}, 1100{ }^{\circ} \mathrm{C}, 1000^{\circ} \mathrm{C}, 950{ }^{\circ} \mathrm{C}, 900{ }^{\circ} \mathrm{C} ;(\mathbf{e}): \mathrm{T}=7 \mathrm{kbar}$, and $\mathrm{T}=1500{ }^{\circ} \mathrm{C}, 1400{ }^{\circ} \mathrm{C}, 1300{ }^{\circ} \mathrm{C}, 1200{ }^{\circ} \mathrm{C}, 1100{ }^{\circ} \mathrm{C}, 1000{ }^{\circ} \mathrm{C}, 950{ }^{\circ} \mathrm{C}, 900{ }^{\circ} \mathrm{C}, 850{ }^{\circ} \mathrm{C}$; (f): $\mathrm{T}=8 \mathrm{kbar}$, and $\mathrm{T}=1500{ }^{\circ} \mathrm{C}, 1400{ }^{\circ} \mathrm{C}, 1300{ }^{\circ} \mathrm{C}, 1200{ }^{\circ} \mathrm{C}, 1100{ }^{\circ} \mathrm{C}, 1000{ }^{\circ} \mathrm{C}$. Mafic end member from Wang et al. [40].

\subsection{Geodynamic Implications}

Previous studies suggest that the formation ages of Mesozoic A-type granitoids or alkaline intrusions in South China become younger from west to east and are generally older than $120 \mathrm{Ma}$ in the west of the Zhenghe-Dapu fault (Figure 1) [8,113]. The Muchen pluton is metaluminous to weakly peraluminous A-type granitoids. However, the Muchen pluton has younger zircon U-Pb age ( $111 \mathrm{Ma}$; Figure 5) than those A-type granitoids distributed in the west of the Zhenghe-Dapu fault, but older age than those these A-type granitoids distributed in coastal area $(\sim 100-90 \mathrm{Ma})[8,14,114,115]$, thus providing an opportunity to refine the model for the origin of A-type granitoids and further constrain the Cretaceous tectonic evolution of South China. 
During the Late Yanshanian, large-scale and regional lithospheric extension has been identified due to the widespread A-type granites or alkaline rocks [8], intraplate basalts [3], bimodal volcanic rocks [116], and metamorphic core complexes [117] in Southeast China. A-type magmas are typically produced in an extensional tectonic setting (e.g., back-arc extension, continental arc, post-collisional extension, and within-plate settings; [72]). The Early Cretaceous A-type granitoids for the Muchen pluton distributed near the boundary between $\mathrm{A}_{1}$-type magma and $\mathrm{A}_{2}$-type magma (Figure $8 \mathrm{~d}$ ). Similarly, these rocks also plotting in both volcanic arc granite (VAG) and within-plate granite (WPG) field (Figure 18). Liu et al. [118] propose that SE China underwent an asynchronizing paleo-Pacific slab rollback process during the early-stage of early Cretaceous (145-110 Ma), then a back-arc tectonic setting occurred due to the subduction angle of paleo-Pacific plate become steeper. Other authors also suggest that the tectonic setting of SE China changed from a compressional subduction regime to an extensional regime during the Cretaceous time due to a progressive increase in the subduction angle of the paleo-Pacific plate, which corresponding transition time at approximately $110 \mathrm{Ma}[14,119]$. The Muchen pluton emplaced at $111 \mathrm{Ma}$, and all the samples are enriched in LILEs and LREE, but depleted in HFSEs, which suggesting a subduction-related environment $[18,30,120-122]$. Thus, a series of evidence show that the Muchen pluton most likely generated in a back-arc extensional setting due to the subduction angle of the paleo-Pacific slab become steeper during the Early Cretaceous. Meanwhile, the low Mg\# values of Muchen rocks indicate a low-pressure feature, which is consistent with the extensional setting. Therefore, the extensional regime of SE China may be existence before $110 \mathrm{Ma}$, which gives a proper environment to produce the Muchen alkaline rocks.

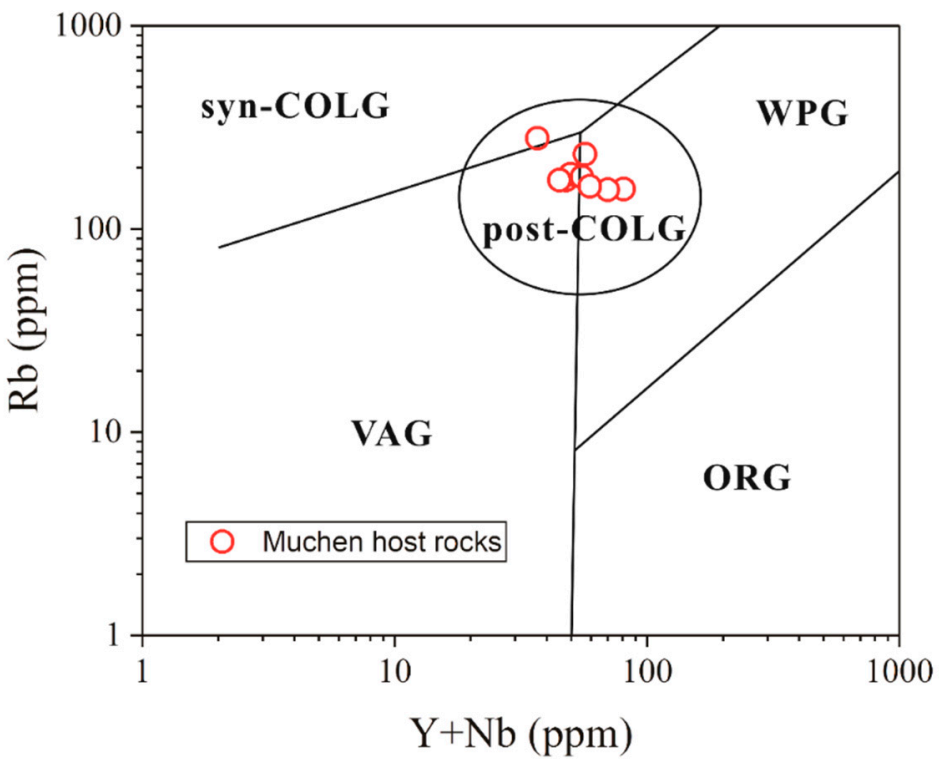

Figure 18. Tectonic discrimination diagrams for the Muchen alkaline rocks [123]. The field for post-collision granite (post-COLG) from Pearce [120]. Abbreviations: syn-COLG: syn-collision granite; post COLG: post-collision granite; WPG: within-plate granite; ORG: ocean ridge granite; VAG: volcanic arc granite.

In summary, we propose a simplified genetic model for the Muchen quartz monzonite: (1) the normal subduction of the paleo-Pacific plate contributed subduction-related melts/fluids and trace elements such as $\mathrm{Nb}, \mathrm{Ta}, \mathrm{U}, \mathrm{K}$ to the sub-continental lithospheric mantle; (2) the increasing subduction angle of the paleo-Pacific plate caused lithosphere extension and asthenospheric mantle upwelling; (3) and triggered partial melting of the enriched mantle induced by metasomatism of slab derived fluids and melts. (4) Subsequently, the primary basaltic magma experienced strongly fractional crystallization of olivine + pyroxene + spinel + plagioclase as it ascended, which produced the Muchen alkaline quartz monzonite. 


\section{Conclusions}

(1) The Muchen rocks are mainly K-rich alkaline A-type quartz monzonites, generated in the Early Cretaceous ( 111 Ma).

(2) The Muchen quartz monzonites have homogeneous isotopic compositions, with $\left({ }^{87} \mathrm{Sr} /{ }^{86} \mathrm{Sr}\right)_{i}=$ 0.7052 to $0.7070, \varepsilon_{\mathrm{Nd}}(t)=-3.2$ to $-2.0, \varepsilon_{\mathrm{Hf}}(t)=-1.7$ to +2.6 . The primitive magma of the Muchen quartz monzonites was derived partial melting of slab derived melts (mainly) and fluids metasomatized mantle. This magma experienced strongly fractional crystallization of olivine + pyroxene + spinel + plagioclase as it ascended, which produced the Muchen alkaline quartz monzonite.

(3) The MMEs also have homogeneous isotopic compositions, with $\left({ }^{87} \mathrm{Sr} /{ }^{86} \mathrm{Sr}\right)_{i}=0.7062$ to 0.7065 and $\varepsilon_{\mathrm{Nd}}(t)=-2.6$ to +0.6 . They are fragments of recrystallized or melt residues from the Muchen magma source, or early formed crystals.

(4) Low Mg\# values of the Muchen alkaline rock were formed in a back-arc extension setting, due to deep angle subduction of the paleo-Pacific plate during the Early Cretaceous.

Supplementary Materials: The following are available online at http://www.mdpi.com/2075-163X/10/1/80/s1: Supplementary S1: Zircon LA-ICP-MS U-Pb dating results of representative samples from Muchen pluton. Supplementary S2: Zircon in situ LA-MC-ICPMS Hf isotopic compositions of representative samples from Muchen pluton. Supplementary S3: Zircon LA-ICP-MS rare earth elements results of representative samples from Muchen pluton. Supplementary S4: Results of MELTs simulation.

Author Contributions: Conceptualization and Writing-Original Draft Preparation by H.Y. and F.W.; Hafnium isotopes analysis by H.-O.G. and H.S.; Data process by C.G.; All authors have read and agreed to the published version of the manuscript.

Funding: This worked was funded by National Key R\&D Program of China (Grant number 2016YFC0600404 and 2016YFC0600206), Natural Science Foundation of China (Grant number 41873034), and the Fundamental Research Funds for the Central Universities (Grant number PA2018GDQT0020).

Acknowledgments: We thank Nengping Shen for whole rock major, trace and $\mathrm{Sr}-\mathrm{Nd}-\mathrm{Pb}$ isotope analysis. Thanks to Qiuyuan Yuan for zircon CL photograph. Especially thanks to Peter Hollings and Noel White for polishing the English for the English version.

Conflicts of Interest: The authors declare no conflict of interest.

\section{References}

1. Hsieh, P.-S.; Chen, C.-H.; Yang, H.-J.; Lee, C.-Y. Petrogenesis of the Nanling Mountains granites from South China: Constraints from systematic apatite geochemistry and whole-rock geochemical and $\mathrm{Sr}-\mathrm{Nd}$ isotope compositions. J. Asian Earth Sci. 2008, 33, 428-451. [CrossRef]

2. Wang, Q.; Li, J.-W.; Jian, P.; Zhao, Z.-H.; Xiong, X.-L.; Bao, Z.-W.; Xu, J.-F.; Li, C.-F.; Ma, J.-L. Alkaline syenites in eastern Cathaysia (South China): Link to Permian-Triassic transtension. Earth Planet. Sci. Lett. 2005, 230, 339-354. [CrossRef]

3. Li, X.-H. Cretaceous magmatism and lithospheric extension in Southeast China. J. Asian Earth Sci. 2000, 18, 293-305. [CrossRef]

4. Li, X.-H.; Li, Z.-X.; Li, W.-X.; Liu, Y.; Yuan, C.; Wei, G.; Qi, C. U-Pb zircon, geochemical and Sr-Nd-Hf isotopic constraints on age and origin of Jurassic I- and A-type granites from central Guangdong, SE China: A major igneous event in response to foundering of a subducted flat-slab? Lithos 2007, 96, 186-204. [CrossRef]

5. Lapierre, H.; Jahn, B.; Charvet, J.; Yu, Y. Mesozoic felsic arc magmatism and continental olivine tholeiites in Zhejiang Province and their relationship with the tectonic activity in southeastern China. Tectonophysics 1997, 274, 321-338. [CrossRef]

6. Li, Z.; Wang, X.-C.; Wilde, S.A.; Liu, L.; Li, W.-X.; Yang, X.-M. Role of deep-Earth water cycling in the growth and evolution of continental crust: Constraints from Cretaceous magmatism in southeast China. Lithos 2018, 302, 126-141. [CrossRef]

7. Liu, L.; Qiu, J.-S.; Zhao, J.-L. A hybrid origin for two Cretaceous monzonitic plutons in eastern Zhejiang Province, Southeast China: Geochronological, geochemical, and Sr-Nd-Hf isotopic evidence. J. Asian Earth Sci. 2016, 115, 183-203. [CrossRef] 
8. Wang, Q.; Zhao, Z.H.; Jian, P.; Xiong, X.L.; Bao, Z.W.; Dai, Z.M.; Xu, J.F.; Ma, J.L. Geochronology of Cretaceous A-type granitoids or alkaline intrusive rocks in the hinterland, South China: Constrains for late-Mesozoic tectonic evolution. Acta Petrol. Sin. 2005, 21, 795-808, (In Chinese with English Abstract).

9. Chen, J.-Y.; Yang, J.-H.; Zhang, J.-H.; Sun, J.-F.; Wilde, S.A. Petrogenesis of the Cretaceous Zhangzhou batholith in southeastern China: Zircon U-Pb age and Sr-Nd-Hf-O isotopic evidence. Lithos 2013, 162, 140-156. [CrossRef]

10. Hu, Q.; Yu, K.; Liu, Y.; Hu, Z.; Zong, K. The 131-134 Ma A-type granites from northern Zhejiang Province, South China: Implications for partial melting of the Neoproterozoic lower crust. Lithos 2017, 294, 39-52. [CrossRef]

11. Jiang, Y.-H.; Zhao, P.; Zhou, Q.; Liao, S.-Y.; Jin, G.-D. Petrogenesis and tectonic implications of Early Cretaceous S- and A-type granites in the northwest of the Gan-Hang rift, SE China. Lithos 2011, 121, 55-73. [CrossRef]

12. Li, B.; Jiang, S.-Y.; Lu, A.-H.; Zhao, H.-X.; Yang, T.-L.; Hou, M.-L. Zircon U-Pb dating, geochemical and $\mathrm{Sr}-\mathrm{Nd}-\mathrm{Hf}$ isotopic characteristics of the Jintonghu monzonitic rocks in western Fujian Province, South China: Implication for Cretaceous crust-mantle interactions and lithospheric extension. Lithos 2016, 260, 413-428. [CrossRef]

13. Qiu, J.S.; Wang, D.Z.; Mcinnes BI, A. Geochemistry and petrogenesis of the I-and S-type composite granite masses in the coastal area of Zhejiang and Fujian province. Acta Petrol. Sin. 1999, 15, 237-246, (In Chinese with English Abstract).

14. He, Z.-Y.; Xu, X.-S. Petrogenesis of the Late Yanshanian mantle-derived intrusions in southeastern China: Response to the geodynamics of paleo-Pacific plate subduction. Chem. Geol. 2012, 328, 208-221. [CrossRef]

15. Sylvester, P.J. Post-Collisional Alkaline Granites. J. Geol. 1989, 97, 261-280. [CrossRef]

16. Whalen, J.B.; Currie, K.L.; Chappell, B.W. A-type granites: Geochemical characteristics, discrimination and petrogenesis. Contrib. Miner. Pet. 1987, 95, 407-419. [CrossRef]

17. Zhu, Y.-S.; Yang, J.-H.; Sun, J.-F.; Wang, H. Zircon Hf-O isotope evidence for recycled oceanic and continental crust in the sources of alkaline rocks. Geology 2017, 45, 407-410. [CrossRef]

18. Clemens, J.D.; Holloway, J.R.; White, A.J.R. Origin of an A-type granite: Experimental constraints. Am. Mineral. 1986, 71, 317-324.

19. Collins, W.J.; Beams, S.D.; White, A.J.R.; Chappell, B.W. Nature and origin of A-type granites with particular reference to southeastern Australia. Contrib. Miner. Pet. 1982, 80, 189-200. [CrossRef]

20. Auwera, J.V.; Bogaerts, M.; Liégeois, J.-P.; Demaiffe, D.; Wilmart, E.; Bolle, O.; Duchesne, J.C. Derivation of the 1.0-0.9 Ga ferro-potassic A-type granitoids of southern Norway by extreme differentiation from basic magmas. Precambrian Res. 2003, 124, 107-148. [CrossRef]

21. Frost, C.D.; Frost, B.R. Reduced rapakivi-type granites: The tholeiite connection. Geology 1997, 25, 647-650. [CrossRef]

22. Douce, A.E.P. Generation of metaluminous A-type granites by low-pressure melting of calc-alkaline granitoids. Geology 1997, 25, 743-746. [CrossRef]

23. King, P.; Allen, C.M.; Chappell, B.W.; White, A.J.R. Are A-type granites the high-temperature felsic granites? Evidence from fractionated granites of the Wangrah Suite. Aust. J. Earth Sci. 2001, 48, 501-514. [CrossRef]

24. Aghazadeh, M.; Castro, A.; Omran, N.R.; Emami, M.H.; Moinvaziri, H.; Badrzadeh, Z. The gabbro (shoshonitic)-monzonite-granodiorite association of Khankandi pluton, Alborz Mountains, NW Iran. J. Asian Earth Sci. 2010, 38, 199-219. [CrossRef]

25. He, Z.; Xu, X.; Yu, Y.; Zou, H. Origin of the Late Cretaceous syenite from Yandangshan, SE China, constrained by zircon $\mathrm{U}-\mathrm{Pb}$ and $\mathrm{Hf}$ isotopes and geochemical data. Int. Geol. Rev. 2009, 51, 556-582. [CrossRef]

26. Jiang, Y.-H.; Jiang, S.-Y.; Ling, H.-F.; Zhou, X.-R.; Rui, X.-J.; Yang, W.-Z. Petrology and geochemistry of shoshonitic plutons from the western Kunlun orogenic belt, Xinjiang, northwestern China: Implications for granitoid geneses. Lithos 2002, 63, 165-187. [CrossRef]

27. Liu, S.; Hu, R.; Gao, S.; Feng, C.; Qi, Y.; Wang, T.; Feng, G.; Coulson, I.M. U-Pb zircon age, geochemical and $\mathrm{Sr}-\mathrm{Nd}-\mathrm{Pb}-\mathrm{Hf}$ isotopic constraints on age and origin of alkaline intrusions and associated mafic dikes from Sulu orogenic belt, Eastern China. Lithos 2008, 106, 365-379. [CrossRef]

28. Ackerman, L.; Krňanská, M.; Siebel, W.; Strnad, L. Geochemistry of the Drahotín and Mutěnín intrusions, West Bohemian shear zone, Bohemian massif: Contrasting evolution of mantle-derived melts. Miner. Pet. 2010, 99, 185-199. [CrossRef] 
29. Donskaya, T.; Gladkochub, D.; Mazukabzov, A.; Ivanov, A. Late Paleozoic-Mesozoic subduction-related magmatism at the southern margin of the Siberian continent and the 150 million-year history of the Mongol-Okhotsk Ocean. J. Asian Earth Sci. 2013, 62, 79-97. [CrossRef]

30. Liu, L.; Qiu, J.-S.; Li, Z. Origin of mafic microgranular enclaves (MMEs) and their host quartz monzonites from the Muchen pluton in Zhejiang Province, Southeast China: Implications for magma mixing and crust-mantle interaction. Lithos 2013, 160, 145-163. [CrossRef]

31. Mao, J.; Ye, H.; Liu, K.; Li, Z.; Takahashi, Y.; Zhao, X.; Kee, W.-S. The Indosinian collision-extension event between the South China Block and the Palaeo-Pacific plate: Evidence from Indosinian alkaline granitic rocks in Dashuang, eastern Zhejiang, South China. Lithos 2013, 172, 81-97. [CrossRef]

32. Wang, W.; Liu, S.; Bai, X.; Li, Q.; Yang, P.; Zhao, Y.; Zhang, S.-H.; Guo, R. Geochemistry and zircon U-Pb-Hf isotopes of the late Paleoproterozoic Jianping diorite-monzonite-syenite suite of the North China Craton: Implications for petrogenesis and geodynamic setting. Lithos 2013, 162, 175-194. [CrossRef]

33. Wong, J.; Sun, M.; Xing, G.; Li, X.-H.; Zhao, G.; Wong, K.; Yuan, C.; Xia, X.; Li, L.; Wu, F. Geochemical and zircon $\mathrm{U}-\mathrm{Pb}$ and $\mathrm{Hf}$ isotopic study of the Baijuhuajian metaluminous A-type granite: Extension at 125-100 Ma and its tectonic significance for South China. Lithos 2009, 112, 289-305. [CrossRef]

34. Li, L.L.; Zhou, H.W.; Chen, Z.H.; Wang, J.R.; Chen, Z.H.; Xiao, Y. Comparison of A-Type Granites from Talmushan and Gushan Regions in Fujian Province and Their Geodynamic Significance. Geoscience 2013, 27, 509-524.

35. Wang, H.-Z.; Chen, P.-R.; Sun, L.-Q.; Ling, H.-F.; Zhao, Y.-D.; Lan, H.-F. Magma mixing and crust-mantle interaction in Southeast China during the Early Cretaceous: Evidence from the Furongshan granite porphyry and mafic microgranular enclaves. J. Asian Earth Sci. 2015, 111, 72-87. [CrossRef]

36. Zhao, J.-L.; Qiu, J.-S.; Liu, L.; Wang, R.-Q. Geochronological, geochemical and Nd-Hf isotopic constraints on the petrogenesis of Late Cretaceous A-type granites from the southeastern coast of Fujian Province, South China. J. Asian Earth Sci. 2015, 105, 338-359. [CrossRef]

37. Chen, J.; Jahn, B.-M. Crustal evolution of southeastern China: Nd and Sr isotopic evidence. Tectonophysics 1998, 284, 101-133. [CrossRef]

38. Shu, L.; Charvet, J. Kinematics and geochronology of the Proterozoic Dongxiang-Shexian ductile shear zone: With HP metamorphism and ophiolitic melange (Jiangnan Region, South China). Tectonophysics 1996, 267, 291-302. [CrossRef]

39. Sun, L.S.; Zhou, G.Q.; Shi, Y.S.; Yin, J. Study of the High Pressure Metamorphic Blueschist and Its Late Proterozoic Age in the Eastern Jiangnan Belt. Chin. Sci. Bull. 1994, 39, 1200-1204.

40. Wang, Y.-J.; Fan, W.-M.; Guo, F.; Peng, T.-P.; Li, C.-W. Geochemistry of Mesozoic Mafic Rocks Adjacent to the Chenzhou-Linwu fault, South China: Implications for the Lithospheric Boundary between the Yangtze and Cathaysia Blocks. Int. Geol. Rev. 2003, 45, 263-286. [CrossRef]

41. Zhang, Z.; Wang, Y. Crustal structure and contact relationship revealed from deep seismic sounding data in South China. Phys. Earth Planet. Inter. 2007, 165, 114-126. [CrossRef]

42. John, B.; Zhou, X.; Li, J. Formation and tectonic evolution of Southeastern China and Taiwan: Isotopic and geochemical constraints. Tectonophysics 1990, 183, 145-160. [CrossRef]

43. Sun, W.D.; Ling, M.X.; Wang, F.Y.; Ding, X.; Hu, Y.H.; Zhou, J.B.; Yang, X.Y. Pacific plate subduction and Mesozoic geological event in eastern China. Bulletin of Mineralogy, Petrol. Geochem. 2008, 27, 218-225.

44. Liu, Y.; Hu, Z.; Gao, S.; Günther, D.; Xu, J.; Gao, C.; Chen, H. In situ analysis of major and trace elements of anhydrous minerals by LA-ICP-MS without applying an internal standard. Chem. Geol. 2008, 257, $34-43$. [CrossRef]

45. Ning, S.Y.; Wang, F.Y.; Xue, W.D.; Zhou, T.F. Geochemistry of the Baoshan pluton in the Tongling region of the Lower Yangtze River Belt. Geochimica 2017, 46, 397-412, (In Chinese with English Abstract).

46. Wang, F.Y.; Ge, C.; Ning, S.Y.; Nie, L.Q.; Zhong, G.X.; White, N.C. A new approach to LA-ICP-MS mapping and application in geology. Acta Petrol. Sin. 2017, 33, 3422-3436.

47. Jackson, S.E.; Pearson, N.J.; Griffin, W.L.; Belousova, E.A. The application of laser ablation-inductively coupled plasma-mass spectrometry to in situ U-Pb zircon geochronology. Chem. Geol. 2004, 211, 47-69. [CrossRef]

48. Wiedenbeck, M.; Allé, P.; Corfu, F.; Griffin, W.L.; Meier, M.; Oberli, F.; Von Quadt, A.; Roddick, J.; Spiegel, W. Three Natural Zircon Standards for U-Th-Pb, Lu-Hf, Trace Element and Ree Analyses. Geostand. Newsl. 1995, 19, 1-23. [CrossRef] 
49. Ludwig, K.R. ISOPLOT 3.0: A Geochronological Tookit for Microsoft Excel; Berkeley Geochronology Center: Berkeley, CA, USA, 2003.

50. Gu,H.-O.; Sun, H.; Wang, F.; Ge, C.; Zhou, T.; Hai-Ou, G.; He, S. A new practical isobaric interference correction model for the in situ Hf isotopic analysis using laser ablation-multi-collector-ICP-mass spectrometry of zircons with high $\mathrm{Yb} / \mathrm{Hf}$ ratios. J. Anal. At. Spectrom. 2019, 32, 1223-1232. [CrossRef]

51. Li, X.-H.; Long, W.-G.; Li, Q.-L.; Liu, Y.; Zheng, Y.-F.; Yang, Y.-H.; Chamberlain, K.R.; Wan, D.-F.; Guo, C.-H.; Wang, X.-C.; et al. Penglai Zircon Megacrysts: A Potential New Working Reference Material for Microbeam Determination of Hf-O Isotopes and U-Pb Age. Geostand. Geoanal. Res. 2010, 34, 117-134. [CrossRef]

52. Sláma, J.; Košler, J.; Condon, D.J.; Crowley, J.L.; Gerdes, A.; Hanchar, J.M.; Horstwood, M.S.; Morris, G.A.; Nasdala, L.; Norberg, N.; et al. Plešovice zircon-A new natural reference material for $\mathrm{U}-\mathrm{Pb}$ and Hf isotopic microanalysis. Chem. Geol. 2008, 249, 1-35. [CrossRef]

53. Li, X.; Tang, G.; Gong, B.; Yang, Y.; Hou, K.; Hu, Z.; Li, Q.; Liu, Y.; Li, W. Qinghu zircon: A working reference for microbeam analysis of $\mathrm{U}-\mathrm{Pb}$ age and $\mathrm{Hf}$ and $\mathrm{O}$ isotopes. Chin. Sci. Bull. 2013, 58, 4647-4654. [CrossRef]

54. Münker, C.; Scherer, E.; Weyer, S.; Mezger, K. Separation of high field strength elements (Nb, Ta, Zr, Hf) and $\mathrm{Lu}$ from rock samples for MC-ICPMS measurements. Geochem. Geophys. Geosyst. 2001, 2, 2001. [CrossRef]

55. Blichert-Toft, J.; Albarède, F. The Lu-Hf isotope geochemistry of chondrites and the evolution of the mantle-crust system. Earth Planet. Sci. Lett. 1997, 148, 243-258. [CrossRef]

56. Eggins, S.M.; Woodhead, J.D.; Kinsley LP, J.; Mortimer, G.E.; Sylvester, P.; Mcculloch, M.T.; Hergt, J.M.; Handler, M.R. A simple method for the precise determination of $\geq 40$ trace elements in geological samples by ICPMS using enriched isotope internal standardization. Chem. Geol. 1997, 134, 311-326. [CrossRef]

57. Kamber, B.; Greig, A.; Schoenberg, R.; Collerson, K. A refined solution to Earth's hidden niobium: Implications for evolution of continental crust and mode of core formation. Precambrian Res. 2003, 126, 289-308. [CrossRef]

58. Li, B.-P.; Greig, A.; Zhao, J.-X.; Collerson, K.D.; Quan, K.-S.; Meng, Y.-H.; Ma, Z.-L. ICP-MS trace element analysis of Song dynasty porcelains from Ding, Jiexiu and Guantai kilns, north China. J. Archaeol. Sci. 2005, 32, 251-259. [CrossRef]

59. Deniel, C.; Pin, C. Single-stage method for the simultaneous isolation of lead and strontium from silicate samples for isotopic measurements. Anal. Chim. Acta 2001, 426, 95-103. [CrossRef]

60. Míková, J.; Denková, P. Modified chromatographic separation scheme for $\mathrm{Sr}$ and $\mathrm{Nd}$ isotope analysis in geological silicate samples. J. Geosci. 2007, 52, 221-226. [CrossRef]

61. Pin, C.; Zalduegui, J.S. Sequential separation of light rare-earth elements, thorium and uranium by miniaturized extraction chromatography: Application to isotopic analyses of silicate rocks. Anal. Chim. Acta 1997, 339, 79-89. [CrossRef]

62. Wu, G.; Zhu, J.-M.; Tan, D.; Han, G.; Zhang, L.; Ren, K. Accurate and precise determination of lead isotope composition in selected geochemical reference materials. Acta Geochim. 2017, 36, 421-425. [CrossRef]

63. Belousova, E.; Griffin, W.; O'Reilly, S.Y.; Fisher, N. Igneous zircon: Trace element composition as an indicator of source rock type. Contrib. Miner. Pet. 2002, 143, 602-622. [CrossRef]

64. Campbell, I.H.; Stepanov, A.S.; Liang, H.-Y.; Allen, C.M.; Norman, M.D.; Zhang, Y.-Q.; Xie, Y.-W. The origin of shoshonites: New insights from the Tertiary high-potassium intrusions of eastern Tibet. Contrib. Miner. Pet. 2014, 167, 983. [CrossRef]

65. Middlemost, E.A. Naming materials in the magma/igneous rock system. Earth-Sci. Rev. 1994, 37, $215-224$. [CrossRef]

66. Irvine, T.N.; Baragar, W.R.A. A Guide to the Chemical Classification of the Common Volcanic Rocks. Can. J. Earth Sci. 1971, 8, 523-548. [CrossRef]

67. Wright, J.B. A simple alkalinity ratio and its application to questions of non-orogenic granite genesis. Geol. Mag. 2009, 106, 370-384. [CrossRef]

68. Peccerillo, A.; Taylor, S.R. Geochemistry of eocene calc-alkaline volcanic rocks from the Kastamonu area, Northern Turkey. Contrib. Miner. Pet. 1976, 58, 63-81. [CrossRef]

69. Middlemost, E.A.K. Magmas and Magmatic Rocks; Longman Press: London, UK, 1985; p. 266.

70. Chappel, B.W.; White, A.J.R. Two contrasting granite types. Pac. Geol. 1974, 8, 173-174.

71. Maniar, P.D.; Piccoli, P.M. Tectonic discrimination of granitoids. GSA Bull. 1989, 101, 635-643. [CrossRef]

72. Eby, G.N. The A-type granitoids: A review of their occurrence and chemical characteristics and speculations on their petrogenesis. Lithos 1990, 26, 115-134. [CrossRef] 
73. Eby, G.N. Chemical subdivision of the A-type granitoids:Petrogenetic and tectonic implications. Geology 1992, 20, 641. [CrossRef]

74. Sun, S.S.; McDonough, W.F. Chemical and Isotopic Systematics of Oceanic Basalts: Implications for Mantle Composition and Processes; Geological Society: London, UK, 1989; Volume 42, pp. 313-345.

75. McDonough, W.; Sun, S.-S. The composition of the Earth. Chem. Geol. 1995, 120, 223-253. [CrossRef]

76. Chen, C.-H.; Lee, C.-Y.; Shinjo, R. Was there Jurassic paleo-Pacific subduction in South China?: Constraints from $40 \mathrm{Ar} / 39 \mathrm{Ar}$ dating, elemental and $\mathrm{Sr}-\mathrm{Nd}-\mathrm{Pb}$ isotopic geochemistry of the Mesozoic basalts. Lithos 2008, 106, 83-92. [CrossRef]

77. Meng, L.; Li, Z.-X.; Chen, H.; Li, X.-H.; Wang, X.-C. Geochronological and geochemical results from Mesozoic basalts in southern South China Block support the flat-slab subduction model. Lithos 2012, 132, 127-140. [CrossRef]

78. Hart, S.R. A large-scale isotope anomaly in the Southern Hemisphere mantle. Nature 1984, 309, $753-757$. [CrossRef]

79. Zindler, A.; Hart, S. Chemical Geodynamics. Annu. Rev. Earth Planet. Sci. 1986, 14, 493-571. [CrossRef]

80. Li, X.-H.; Chung, S.-L.; Zhou, H.; Lo, C.-H.; Liu, Y.; Chen, C.-H. Jurassic intraplate magmatism in southern Hunan-eastern Guangxi: 40Ar/39Ar dating, geochemistry, Sr-Nd isotopes and implications for the tectonic evolution of SE China. Geol. Soc. Lond. Spéc. Publ. 2004, 226, 193-215. [CrossRef]

81. Chen, R.; Zhou, J.C. Information of crust-mantle interaction implied in early Cretaceous composite lavas and dikes from eastern Zhejiang. Geol. Rev. 1999, 5, 784-795, (In Chinese with English Abstract).

82. Shen, W.Z.; Ling, H.F.; Wang, D.Z.; Xu, B.T.; Yu, Y.W. Study on Nd-Sr isotopes of Mesozoic igneous rocks in Zhejiang, China. Sci. Geol. Sin. 1999, 34, 223-232, (In Chinese with English Abstract).

83. Yang, Z.L.; Shen, W.Z.; Tao, K.Y.; Shen, J.L. Sr, Nd and Pb isotopic characteristics of early Cretaceous basaltic rocks from the coast of Zhejiang and Fujian: Evidences for ancient enriched mantle source. Sci. Geol. Sin. 1999, 34, 59-68, (In Chinese with English Abstract).

84. Miller, R.G.; O'Nions, R.K. Source of Precambrian chemical and clastic sediments. Nature 1985, 314, $325-330$. [CrossRef]

85. Wu, F.-Y.; Jahn, B.-M.; Wilde, S.A.; Lo, C.-H.; Yui, T.-F.; Lin, Q.; Ge, W.-C.; Sun, D.-Y. Highly fractionated I-type granites in NE China (II): Isotopic geochemistry and implications for crustal growth in the Phanerozoic. Lithos 2003, 67, 191-204. [CrossRef]

86. Watson, E.B.; Harrison, T.M. Zircon saturation revisited: Temperature and composition effects in a variety of crustal magma types. Earth Planet. Sci. Lett. 1983, 64, 295-304. [CrossRef]

87. Watson, E.B.; Wark, D.A.; Thomas, J.B. Crystallization thermometers for zircon and rutile. Contrib. Miner. Pet. 2006, 151, 413-433. [CrossRef]

88. Fu, B.; Page, F.Z.; Cavosie, A.J.; Fournelle, J.; Kita, N.T.; Lackey, J.S.; Wilde, S.A.; Valley, J.W. Ti-in-zircon thermometry: Applications and limitations. Contrib. Miner. Pet. 2008, 156, 197-215. [CrossRef]

89. Boehnke, P.; Watson, E.B.; Trail, D.; Harrison, T.M.; Schmitt, A.K. Zircon saturation re-revisited. Chem. Geol. 2013, 351, 324-334. [CrossRef]

90. Ferry, J.M.; Watson, E.B. New thermodynamic models and revised calibrations for the Ti-in-zircon and Zr-in-rutile thermometers. Contrib. Miner. Pet. 2007, 154, 429-437. [CrossRef]

91. Gao, X.Y.; Zheng, Y.F. On the Zr-in-rutile and Ti-in-Zircon geothermometers. Acta Petrol. Sin. 2011, 27, 417-432, (In Chinese with English Abstract).

92. Wang, F.; Liu, S.-A.; Li, S.; He, Y. Contrasting zircon Hf-O isotopes and trace elements between ore-bearing and ore-barren adakitic rocks in central-eastern China: Implications for genetic relation to $\mathrm{Cu}-\mathrm{Au}$ mineralization. Lithos 2013, 156, 97-111. [CrossRef]

93. Goldschmidt, V.M. "Kristallchemie", Handwörterbuch der Naturwissenschaften, 2nd ed.; Nature Publishing Group (NPG): Berlin, Germany, 1934.

94. Dostal, J.; Chatterjee, A. Contrasting behaviour of $\mathrm{Nb} / \mathrm{Ta}$ and $\mathrm{Zr} / \mathrm{Hf}$ ratios in a peraluminous granitic pluton (Nova Scotia, Canada). Chem. Geol. 2000, 163, 207-218. [CrossRef]

95. Foley, S.F.; Barth, M.G.; Jenner, G.A. Rutile/melt partition coefficients for trace elements and an assessment of the influence of rutile on the trace element characteristics of subduction zone magmas. Geochim. Cosmochim. Acta 2000, 64, 933-938. [CrossRef]

96. Green, T.H. Significance of $\mathrm{Nb} / \mathrm{Ta}$ as an indicator of geochemical processes in the crust-mantle system. Chem. Geol. 1995, 120, 347-359. [CrossRef] 
97. Guo, F.; Fan, W.; Wang, Y.; Zhang, M. Origin of early Cretaceous calc-alkaline lamprophyres from the Sulu orogen in eastern China: Implications for enrichment processes beneath continental collisional belt. Lithos 2004, 78, 291-305. [CrossRef]

98. Hofmann, A.; Jochum, K.; Seufert, M.; White, W. Nb and Pb in oceanic basalts: New constraints on mantle evolution. Earth Planet. Sci. Lett. 1986, 79, 33-45. [CrossRef]

99. Linnen, R.L.; Keppler, H. Columbite solubility in granitic melts: Consequences for the enrichment and fractionation of $\mathrm{Nb}$ and Ta in the Earth's crust. Contrib. Miner. Pet. 1997, 128, 213-227. [CrossRef]

100. Rudnick, R.L.; Gao, S. Composition of the Continental Crust. Treatise Geochem. 2014, 3, 1-51.

101. Foley, S.; Tiepolo, M.; Vannucci, R. Growth of early continental crust controlled by melting of amphibolite in subduction zones. Nature 2002, 417, 837-840. [CrossRef] [PubMed]

102. Şen, C.; Dunn, T. Dehydration melting of a basaltic composition amphibolite at 1.5 and 2.0 GPa: Implications for the origin of adakites. Contrib. Miner. Pet. 1994, 117, 394-409. [CrossRef]

103. Stolz, A.J.; Jochum, K.P.; Spettel, B.; Hofmann, A.W. Fluid- and melt-related enrichment in the subarc mantle: Evidence from $\mathrm{Nb} / \mathrm{Ta}$ variations in island-arc basalts. Geology 1996, 24, 587-590. [CrossRef]

104. Zhang, B.; Guo, F.; Zhang, X.; Wu, Y.; Wang, G.; Zhao, L. Early Cretaceous subduction of Paleo-Pacific Ocean in the coastal region of SE China: Petrological and geochemical constraints from the mafic intrusions. Lithos 2019, 334, 8-24. [CrossRef]

105. Ayers, J. Trace element modeling of aqueous fluid - peridotite interaction in the mantle wedge of subduction zones. Contrib. Miner. Pet. 1998, 132, 390-404. [CrossRef]

106. Xu, X.; O’Reilly, S.Y.; Griffin, W.L.; Wang, X.; Pearson, N.; He, Z. The crust of Cathaysia: Age, assembly and reworking of two terranes. Precambrian Res. 2007, 158, 51-78. [CrossRef]

107. He, Z.-Y.; Xu, X.-S.; Niu, Y. Petrogenesis and tectonic significance of a Mesozoic granite-syenite-gabbro association from inland South China. Lithos 2010, 119, 621-641. [CrossRef]

108. Rudnick, R.L.; Barth, M.; Horn, I.; McDonough, W.F. Rutile-Bearing Refractory Eclogites: Missing Link Between Continents and Depleted Mantle. Sci. 2000, 287, 278-281. [CrossRef] [PubMed]

109. Workman, R.K.; Hart, S.R. Major and trace element composition of the depleted MORB mantle (DMM). Earth Planet. Sci. Lett. 2005, 231, 53-72. [CrossRef]

110. Li, Z.; Qiu, J.S.; Xu, X.S. Geochronological, geochemical and Sr-Nd-Hf isotopic constraints on petrogenesis of Late Mesozoic gabbro-granite complexes on the southeast coast of Fujian, South China: Insights into a depleted mantle source region and crust-mantle interactions. Geol. Mag. 2012, 149, 459-482. [CrossRef]

111. Rapp, R.P.; Watson, E.B. Dehydration Melting of Metabasalt at 832- kbar: Implications for Continental Growth and Crust-Mantle Recycling. J. Pet. 1995, 36, 891-931. [CrossRef]

112. Gualda GA, R.; Ghiorso, M.S. MELTS_Excel: A Microsoft Excel-based MELTS interface for research and teaching of magma properties and evolution. Geochem. Geophys. Geosyst. 2015, 16, 315-324. [CrossRef]

113. Liu, L.; Xu, X.; Xia, Y. Cretaceous Pacific plate movement beneath SE China: Evidence from episodic volcanism and related intrusions. Tectonophysics 2014, 614, 170-184. [CrossRef]

114. Yan, L.-L.; He, Z.-Y.; Jahn, B.-M.; Zhao, Z.-D. Formation of the Yandangshan volcanic-plutonic complex (SE China) by melt extraction and crystal accumulation. Lithos 2016, 266, 287-308. [CrossRef]

115. Chen, J.-Y.; Yang, J.-H.; Zhang, J.-H.; Sun, J.-F. Geochemical transition shown by Cretaceous granitoids in southeastern China: Implications for continental crustal reworking and growth. Lithos 2014, 196, 115-130. [CrossRef]

116. Zhang, B.T.; Chen, P.R.; Kong, X.G. Rb-Sr chronology of bimodal volcanic rocks of the Yutian Group in the Linjiang basin, southern Jiangxi. Chin. Geol. 2002, 29, 351-354, (In Chinese with English Abstract).

117. Lin, W.; Faure, M.; Sun, Y.; Shu, L.; Wang, Q. Compression to extension switch during the Middle Triassic orogeny of Eastern China: The case study of the Jiulingshan massif in the southern foreland of the Dabieshan. J. Asian Earth Sci. 2001, 20, 31-43. [CrossRef]

118. Liu, L.; Xu, X.; Xia, Y. Asynchronizing paleo-Pacific slab rollback beneath SE China: Insights from the episodic Late Mesozoic volcanism. Gondwana Res. 2016, 37, 397-407. [CrossRef]

119. Zhou, X.; Sun, T.; Shen, W.; Shu, L.; Niu, Y. Petrogenesis of Mesozoic granitoids and volcanic rocks in South China: A response to tectonic evolution. Episodes 2006, 29, 26-33. [CrossRef]

120. Pearce, J. Sources and settings of granitic rocks. Episodes 1996, 19, 120-125. [CrossRef]

121. Rogers, G.; Hawkesworth, C.J. A geochemical traverse across the North Chilean Andes: Evidence for crust generation from the mantle wedge. Earth Planet. Sci. Lett. 1989, 91, 271-285. [CrossRef] 
122. Sajona, F.G.; Maury, R.C.; Bellon, H.; Cotten, J.; Defant, M. High Field Strength Element Enrichment of Pliocene-Pliocene Island Arc Basalts, Mindanao (Philippines). J. Petrol. 1996, 37, 693-726. [CrossRef]

123. Pearce, J.A.; Harris, N.B.W.; Tindle, A.G. Trace Element Discrimination Diagrams for the Tectonic Interpretation of Granitic Rocks. J. Pet. 1984, 25, 956-983. [CrossRef]

(C) 2020 by the authors. Licensee MDPI, Basel, Switzerland. This article is an open access article distributed under the terms and conditions of the Creative Commons Attribution (CC BY) license (http://creativecommons.org/licenses/by/4.0/). 